\title{
Evolutionary and Structural Diversification of the Larval Nervous System Among Marine Bryozoans
}

\author{
SCOTT SANTAGATA* \\ Smithsonian Marine Station, 701 Seaway Drive, Fort Pierce, Florida 34949
}

\begin{abstract}
Regardless of the morphological divergence among larval forms of marine bryozoans, the larval nervous system and its major effector organs (musculature and ciliary fields) are largely molded on the basis of functional demands of feeding, ciliary propulsion, phototactic behaviors, and substrate exploration. Previously published ultrastructural information and immunohistochemical reconstructions presented here indicate that neuronal pathways are largely ipsilateral, with more complex synaptic connections localized within the nerve nodule. Multiciliated sensory-motor neurons diversify structurally and functionally on the basis of their position along the axis of swimming largely due to the functional demands of photoklinotaxis and substrate exploration. Vesiculariform, buguliform, and ascophoran coronate larvae all have patches of sensory neurons bordering the pyriform organ's ciliated groove (juxtapapillary cells and border cells) that are active during substrate selection. Despite their simplified form, cyclostome larvae maintain swimming and probing behaviors with sensory-motor systems functionally similar to those of some parenchymella and planula larval types. Considering the evolutionary relationships among the morphological grades of marine bryozoans, particular lineages within the gymnolaemates have independently evolved larval traits that convey a greater range of sensory abilities and increased propulsive capacity. The larval nervous system of bryozoans may be evolutionarily derived from the pretrochal region of a trochophore-like larval form.
\end{abstract}

\section{Introduction}

Descriptive studies of the larval nervous systems of marine invertebrates have yielded crucial insights into the

Received 10 January 2008; accepted 13 February 2008.

* To whom correspondence should be addressed, at Smithsonian Environmental Research Center, Marine Invasions Laboratory, 647 Contees Wharf Road, Edgewater, MD 21037. E-mail: scott.santagata@gmail.com development (Bishop and Burke, 2007), function (Kempf and Page, 2005), and evolution of metazoan life histories (Strathmann, 1993). Recent developments in ubiquitous probes, confocal microscopy techniques, and three-dimensional image analyses have resulted in what has been called a new "golden age of morphology" (Harrison, 2002). Beyond the increased cytological detail provided by these techniques, functional inferences based on the details of neuronal connections and pathways have greatly improved our understanding of the stimuli received by larval sensory structures and their control over effector organs (Braubach et al., 2006). Regardless of the divergent morphologies observed between feeding and nonfeeding larval forms, many marine invertebrate larval types are subject to convergent selective pressures due to the functional constraints of swimming in the plankton (Chia et al., 1984; Emlet, 1994), responding to external stimuli during active settlement behaviors before metamorphosis (Santagata, 2004a), and the remodeling of larval tissues during metamorphosis (Santagata, 2002; Heyland and Moroz, 2006).

Among metazoans with true nervous systems, phyla within the ecdysozoan and deuterostome lineages (Halanych, 2004) are more similar in their larval and juvenile anatomies than those present among phyla of the Lophotrochozoa. The more divergent morphologies present within the Lophotrochozoa confound traditional evolutionary interpretations of many larval and adult characters, especially with regard to the "lophophorates." More recent studies on the development and larval anatomy of phoronids and brachiopods have expanded our understanding of their evolutionary affinities (Santagata and Zimmer, 2002; Santagata, 2004b; Cohen and Weydmann, 2005). However, often left anatomically and phylogenetically orphaned by these reports, are the bryozoans.

Most extant morphological grades of bryozoans have fossil records that can be definitively traced back to the 
Ordovician, but it is likely that unmineralized bryozoans originated in the Cambrian or earlier with other metazoan phyla (Valentine, 2004; Cartwright and Collins, 2007). Current morphological and molecular phylogenetic evidence resolves the bryozoans within the Lophotrochozoa and suggests that the suite of larval and adult colonial traits expressed by basal ctenostome (uncalcified) bryozoans represents the pleisiomorphic condition for the phylum (Dick et al., 2000; Todd, 2000; Waeshenbach et al., 2006). Recent efforts to broaden the taxonomic scope of knowledge concerning bryozoan larval morphologies have revealed that the structural and functional diversity in the main propulsive ciliary fields and musculature is much greater within nonfeeding ctenostome larval types than in other grades of bryozoans (Santagata, 2008). Much of this structural variation is linked to the musculature involved with tissue rearrangements at metamorphosis and to maximizing the surface area of ciliary fields used for propulsion.

It remains unknown to what extent these anatomical trends are reflected in the larval nervous system of bryozoans and what functional and evolutionary inferences can be drawn from a taxonomically broad study. Previous investigations have primarily depended upon ultrastructural methods, and although these studies have provided a wealth of detailed cytological information on particular species (Reed, 1988; Reed et al., 1988; Zimmer and Woollacott, 1989a, b; Zimmer and Woollacott, 1993), the integration among sensory structures (apical organ, pyriform organ, and intercoronal cells) and their effector organs (propulsive ciliary fields and musculature) of the entire neuromuscular system is not well understood. Perhaps the most significant problem has been the mapping of all neuronal cell types within the nervous system and reconstructing the pathways of sensory/motor fibers in three dimensions. Much of the diversity in ciliary fields has been reviewed (Reed et al., 1988; Reed, 1991; Santagata, 2008), but in general, sensory types are classified by the morphology of their multiciliated tufts and position relative to the main propulsive ciliary fields- the coronal cells and oral ciliated cells. According to this classification scheme, sensory structures are found in three general regions of the larval surface: (1) within a band of oligociliated cells called the supracoronal cells that are positioned aborally to the coronal cells and bordered by the pallial epithelium, (2) between adjacent coronal cells are the intercoronal cells, and (3) within an unciliated (and often undifferentiated) band of cells called the infracoronal cells that are oral to the coronal cells. The classification of sensory cell types is somewhat unclear within particular lineages in which the typical cellular characteristics of the coronal cells have been lost (see Santagata, 2008), and also when any of the previously mentioned cellular bands are either expanded or reduced. In these cases, a comparative study on more closely related species often provides insight into the derivation of ciliary fields and sensory cell types.
The purpose of this study was to compile a broad taxonomic review of bryozoan larval nervous systems that integrates previous ultrastructural studies with recent immunohistochemical evidence. In addition to this previous work, new data were gathered using an antibody that labeled all ciliated and neuronal cell types (acetylated $\alpha$-tubulin) as well as another established probe for an evolutionarily conserved neurotransmitter (serotonin). Other ubiquitous probes that aid in determining general larval anatomy (phalloidin for fibrous actin and propidium iodide for nucleic acids) were used as counterstains, allowing for the definitive classification of neuronal cell bodies, axons, and nerves versus neuronal varicosities and muscle fibers. Three-dimensional reconstructions of labeled tissues were achieved with laser confocal microscopy and several image-analysis software packages. These methods were used to reevaluate previously described species as well as several additional species for which there are few published accounts of larval morphology.

Bryozoan larvae provide a unique opportunity to study the functional and evolutionary implications of neuromuscular variability among the morphologically diverse array of phyla included within the Lophotrochozoa. Here, I demonstrate that regardless of the morphological divergence that is found in the gross larval anatomy among marine bryozoans, the larval nervous system and its major effector organs are largely molded on the basis of the functional demands of feeding, ciliary propulsion, phototactic behaviors, and substrate exploration. Considering the evolutionary relationships among the morphological grades of marine bryozoans, lineages within the ctenostomes and cheilostomes are independently evolving larval traits that convey a greater range of sensory abilities and increased propulsive capacity (Santagata, 2008). The shared absence of specific neuromuscular structures in several lineages is likely the result of convergent evolutionary loss. Despite the differences in sense organs and neuromuscular systems between bryozoans and trochozoans, the collection of larval traits expressed by bryozoans probably evolved from a trochophore-like ancestor and is more similar to those of other lophotrochozoan larval types than to those of ecdysozoans or deuterostomes.

\section{Materials and Methods}

\section{Collection of animals}

Adult colonies of Crisia elongata Milne-Edwards 1838, Nolella stipata Gosse 1855, Amathia vidovici (Heller) 1867, Bowerbankia maxima (Winston, 1982), Bugula stolonifera Ryland 1960, Bugula neritina (Linnaeus) 1758, Celleporaria sherryae Winston 2005, and Schizoporella floridana Osburn 1914 were repeatedly collected between 2002 and 2004 within the Indian River Lagoon, and Aeverrillia setigera (Hinks) 1887 was collected at Sea Horse Key, Florida. Colonies were identified and kept in a dark incubator at 
$23{ }^{\circ} \mathrm{C}$ and aerated for a few days at the Smithsonian Marine Station, Fort Pierce, Florida. These colonies were then exposed to light and released their brooded, competent larvae. Competent larval stages of Membranipora membranacea Linnaeus 1767 were collected from the plankton near the dock at Friday Harbor Laboratories, Friday Harbor, Washington, during April 2005.

\section{Microscopy}

Light micrographs of live larvae crawling on glass slides were taken with a Leica DMLB microscope using a polarizing filter and a Nikon Coolpix 995 camera. For staining of neurons and cilia, larvae were anesthetized in a 2:1 mixture of filtered seawater and $7.5 \%$ magnesium chloride for 20 min prior to fixation. Specimens were fixed overnight at 4 ${ }^{\circ} \mathrm{C}$ in a $4 \%$ paraformaldehyde solution in $0.1 \mathrm{~mol} 1^{-1}$ Sorenson's phosphate buffer $(\mathrm{pH}=7.4)$. Larvae were removed from this solution, and larval tissues were permeabilized with $0.1 \mathrm{~mol} \mathrm{l}^{-1}$ Sorenson's phosphate buffer and $0.1 \%-0.3 \%$ Triton-X detergent for $24 \mathrm{~h}$ at $4{ }^{\circ} \mathrm{C}$ before proceeding with the staining protocol. All further steps were carried out on a rotary shaker table. The immunohistochemistry protocol followed Santagata (2002). Nonspecific sites were blocked with $3 \%$ normal goat serum (S-1000, Vector Laboratories, Burlingame, CA) in PTA solution (GS-PTA) for $24 \mathrm{~h}$ at $4{ }^{\circ} \mathrm{C}$. The primary antibody (anti-acetylated $\alpha$-tubulin, T-6793, Sigma-Aldrich, St. Louis, MO) was diluted 1:500 with 3\% GS-PTA and incubated with the larvae for $48 \mathrm{~h}$ at $4{ }^{\circ} \mathrm{C}$. Experiments with rabbit anti-serotonin (Diasorin, Stillwater, MN) followed the same procedure. The fixed larvae were exposed to both of the previous antibodies at the same time for dual labeling. Specimens were washed (three times) in PTA for a total of $24 \mathrm{~h}$. Larvae were exposed to the secondary antibody, goat anti-mouse AlexaFluor 488 or 568 immunoglobin (A21121 or A21124, Invitrogen-Molecular Probes, Eugene, OR), at a dilution of 1:50 for $24 \mathrm{~h}$. Specimens were then counterstained for either fibrous actin or nucleic acids. Fibrous actin was stained with a 1:20 dilution of AlexaFluor 488 phalloidin (A12379, Invitrogen-Molecular Probes) for $1 \mathrm{~h}$. Nucleic acids were stained with a 1:500 dilution of propidium iodide for 10-15 min (P-1304, Invitrogen-Molecular Probes). Negative controls were produced by deleting the primary antibody. Stained larvae were adhered to clean glass slides coated with a poly-L-lysine solution (1:10 dilution, 25988-63-0, Sigma-Aldrich) and put through an alcohol dehydration series using 2-propanol within 4 min. Finally, larvae were cleared in Murray Clear solution (benzyl benzoate: benzyl alcohol 2:1) for 2 min and mounted in the same solution. Slides were kept in the dark at $4{ }^{\circ} \mathrm{C}$ until viewed with a BioRad Radiance 2100 laser confocal system and a Nikon E800 microscope. Individual laser lines were adjusted for each stain, and $\mathrm{z}$-series were gathered in $1-\mu \mathrm{m}$ sections.
Volume renderings, surface renderings, and depth-coded z-projections were made with Voxx version 2 (Indiana University School of Medicine), Image J software version 1.34 (Wayne Rasband, NIH), and LSM image browser (Leica).

Specimens for scanning electron microscopy (SEM) were prepared according to the methods of Reed et al. (1988). Fixed specimens for SEM were mounted on stubs with double-stick tape, then critical-point-dried and sputtercoated with gold-palladium. Larvae were examined with a JEOL JSM 6400V, and digital images were saved directly as TIFF files.

\section{Results}

Current higher systematic groupings for bryozoans above the level of genus are often different depending on the author. This is particularly true of the ctenostome bryozoans (Jebram, 1992; Todd, 2000). What have traditionally been referred to as the carnose and stoloniferous ctenostome bryozoans may not be natural groupings, and the organization of families within superfamily assemblages often depends on the interpretation given to a few zooidal characters. For the reasons discussed in Santagata (2008), I will retain Nolella stipata under the superfamily Victorelloidea. Since many structures and cell types for bryozoan larvae have been originally described from cheilostome bryozoans, it is simplest to begin with these forms. Where information on larval anatomy was published previously for some species (such as Membranipora, Bugula, and Amathia), details of ciliated cell types are reviewed briefly. However, since many of the names of the cell types within bryozoan larvae depend on the arrangement of the large ciliated cells responsible for propulsion (coronal and oral ciliated cells), it becomes difficult to classify intercoronal neurons when the characteristics of the coronal cells have been modified or are lacking in certain genera such as Nolella or Crisia (see Santagata, 2008). Therefore, for neuronal cell types in these cases, I have used more generalized terminology based on the morphology of ciliary fields present in each species.

\section{Class Gymnolaemata: Order Cheilostomatida}

\section{Membranipora membranacea (Superfamily \\ Membraniporoidea): Feeding Cyphonautes Larva}

Late-stage larvae of Membranipora membranacea are similar in shape to a blunt-ended triangle covered in a bivalved shell and are commonly referred to as a cyphonautes larva (Fig. 1A). The coronal cells (C; Fig. 1A) are restricted to a narrow band of numerous ciliated cells at the oral (aft) end of the larva. Anatomical features unique to feeding bryozoan larvae are the ciliated ridges (CS; Fig. 1A) and other ciliated cells of the vestibule that bring food particles to the mouth and gut. Larval structures present in 

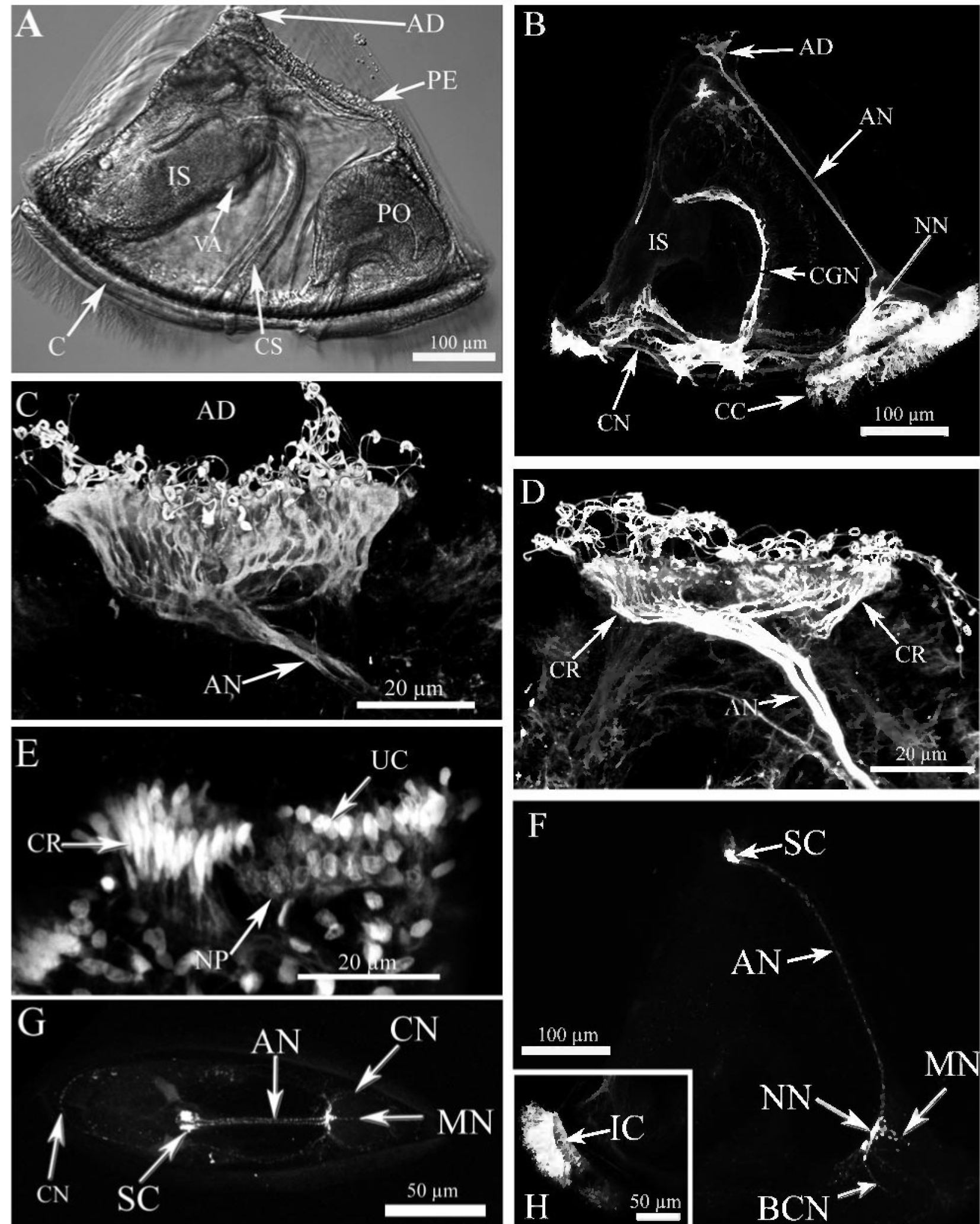

$\mathrm{F}$

$$
4-\mathrm{SC}
$$

$$
\mathrm{AN} \rightarrow
$$

\section{$100 \mu \mathrm{m}$}

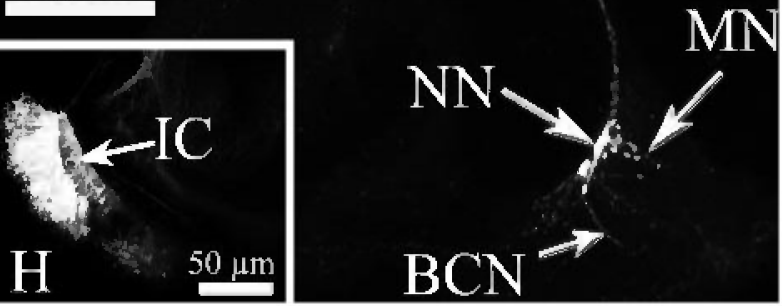


M. membranacea that are also found in nonfeeding forms include the pyriform organ, internal sac, and apical disc (PO, IS, and AD, respectively, Fig. 1A).

Acetylated $\alpha$-tubulin labels all ciliated cells, including the sensory and other neuronal cell types of the nervous system. The nervous system is obscured somewhat within this feeding larval form due to heavily ciliated feeding and locomotory structures such as the ciliated ridges, ciliated cells of the pyriform organ, and coronal cells. Despite the staining of cilia, the paired nerve tracts underlying the ciliated ridges (CGN) and the coronal nerve ring $(\mathrm{CN})$ are apparent (Fig. 1B). Neuronal cell types within the apical disc are clearly visible, as are the paraxial nerve cords (AN) that merge with the nerve nodule (NN) near the pyriform organ (Fig. 1B). All sensory cell types and neuronal cell bodies in the apical disc (AD) are labeled by acetylated $\alpha$-tubulin (Fig. 1C). Discriminating between cells of the ciliated ray (CR) and neural plate (NP) was determined by their relative position within the apical disc and the morphology of their nuclei (Fig. 1D, E; also see Appendix Fig. 1A, B). The fiber projections of these cell types converge beneath the center of the apical disc without any distinct (pyramidal) neuropil-like structure, instead merging into the two paraxial nerve cords. Specimens dual-labeled for both acetylated $\alpha$-tubulin and fibrous actin show that numerous projections from both the apical disc retractor and posterior medial muscle make contact with the base of neuronal cell bodies in the apical disc (see Appendix Fig. 1A). Of all the neuronal cell bodies in the apical disc, only two are labeled by serotonin (Fig. 1F). A single axonal fiber projects orally from each serotonergic cell into the paraxial nerve cords. These fibers meet in the nerve nodule (SC, AN, and NN; Fig. $1 \mathrm{~F}, \mathrm{G})$, after which their individual innervation patterns cannot be followed. Serotonergic nerve fibers are found distal to the nerve nodule within the median nerve cord and the coronal nerve ring ( $\mathrm{MN}$ and $\mathrm{CN}$; Fig. 1G). Positioned between coronal cells are small ciliated neuronal cells (intercoronal cells) that connect with the coronal nerve ring (IC; Fig. 1H).

\section{Celleporaria sherryae (Superfamily Lepralielloidea): Nonfeeding Coronate Larva}

Similar to Membranipora larvae, the nonfeeding coronate larvae of Celleporaria sherryae show acetylated $\alpha$-tubulin labeling in all neuronal and ciliated cell types. Within the apical disc, the ciliated ray cells (CR) have single axonal projections that make ipsilateral contact with the cell bodies of the neural plate cells (NP; Fig. 2A). Paraxial nerve cords merge with the nerve nodule near the pyriform complex (Fig. 2A). Nerve cords (BCN; Fig. 2A) emanate from the nerve nodule along left and right sides of the ciliated groove where they connect with sensory neurons (border cells). The coronal nerve ring (CN; Fig. 2A) was observed in only the most oral third of the larval body where it meets the nerve nodule on the anterior end of the oral groove. At least five pairs (left and right) of sensory neurons (eyespots) have ciliary tufts positioned aboral to the coronal nerve ring. Their cell bodies (OIC; Fig. 2A) are located below the coronal cell layer and send single axonal projections into the nerve ring within which their paths can no longer be traced (OIC; Fig. 2A). The apices of these neuronal cells are darkly pigmented and the neuronal cells are very similar to the intercoronal cell neurons positioned between adjacent coronal cells (IC; Fig. 2B) and differ only in position on the larval surface. Intercoronal cells are present between several

Figure 1. The nervous system of late-stage cyphonautes larvae of Membranipora membranacea. (A) Light micrograph showing the main larval structures including the apical disc (AD), pyriform organ (PO), coronal cells (C), ciliated ridges (CS), internal sac (IS), pallial epithelium (PE), and valve adductor muscle (VA). (B) Late-stage larva labeled for acetylated $\alpha$-tubulin, showing the neuronal cell bodies in the apical dise that merge into the paraxial nerve cords (AN). These nerve cords meet near the pyriform organ at a mass of nerve fibers called the nerve nodule $(\mathrm{NN})$. Other main neuronal structures in this preparation are the coronal nerve ring $(\mathrm{CN})$ and the two nerves that underlie the ciliated ridges (CGN). The eilia of the coronal eells (CC) and other ciliated cell types within the pyriform organ and vestibule are also labeled. (C) Volume projection of neuronal cell bodies in the apical disc labeled with acetylated $\alpha$-tubulin. (D) Sagittal z-projection of the neuronal cell bodies and projections of the ciliated ray cells (CR) within the apical disc labeled with acetylated $\alpha$-tubulin. Fibers from the ciliated ray cells and neural plate cells merge centrally below the apical disc without forming a distinct neuropil and merge into the paraxial nerve cords. (E) Sagittal z-projection of the apical disc labeled for nucleic acids with propidium iodide, showing the different neuronal and undifferentiated cell types within the apical disc. The nuclei of the ciliated ray cells (CR) are compact and uniform-staining; however, the central group of neural plate cells (NP) has granular nuclei. Undifferentiated cells (UC) that contribute to the polypide at metamorphosis are located around and below the apical disc. ( $\mathrm{F}$, lateral view) and ( $\mathrm{G}$, apical view): Late-stage larva labeled for serotonin. Two serotonergic cell bodies (SC) are located within the apical disc and have fibers that are located within the paraxial nerve cords. These nerve cords merge into a mass of neurites within the nerve nodule (NN). Three main nerves connect with the nerve nodule-a median nerve ( $\mathrm{MN}$ ) that innervates a region near the boundary of the coronal cells and the vibratile plume, two nerves that border the ciliated groove (BCN), and the branches of the coronal nerve ring $(\mathrm{CN})$. (H) Sagittal z-projection of coronal cell band, showing the small cell bodies of the intercoronal cells (IC) within the coronal cell region labeled with acetylated $\alpha$-tubulin. 

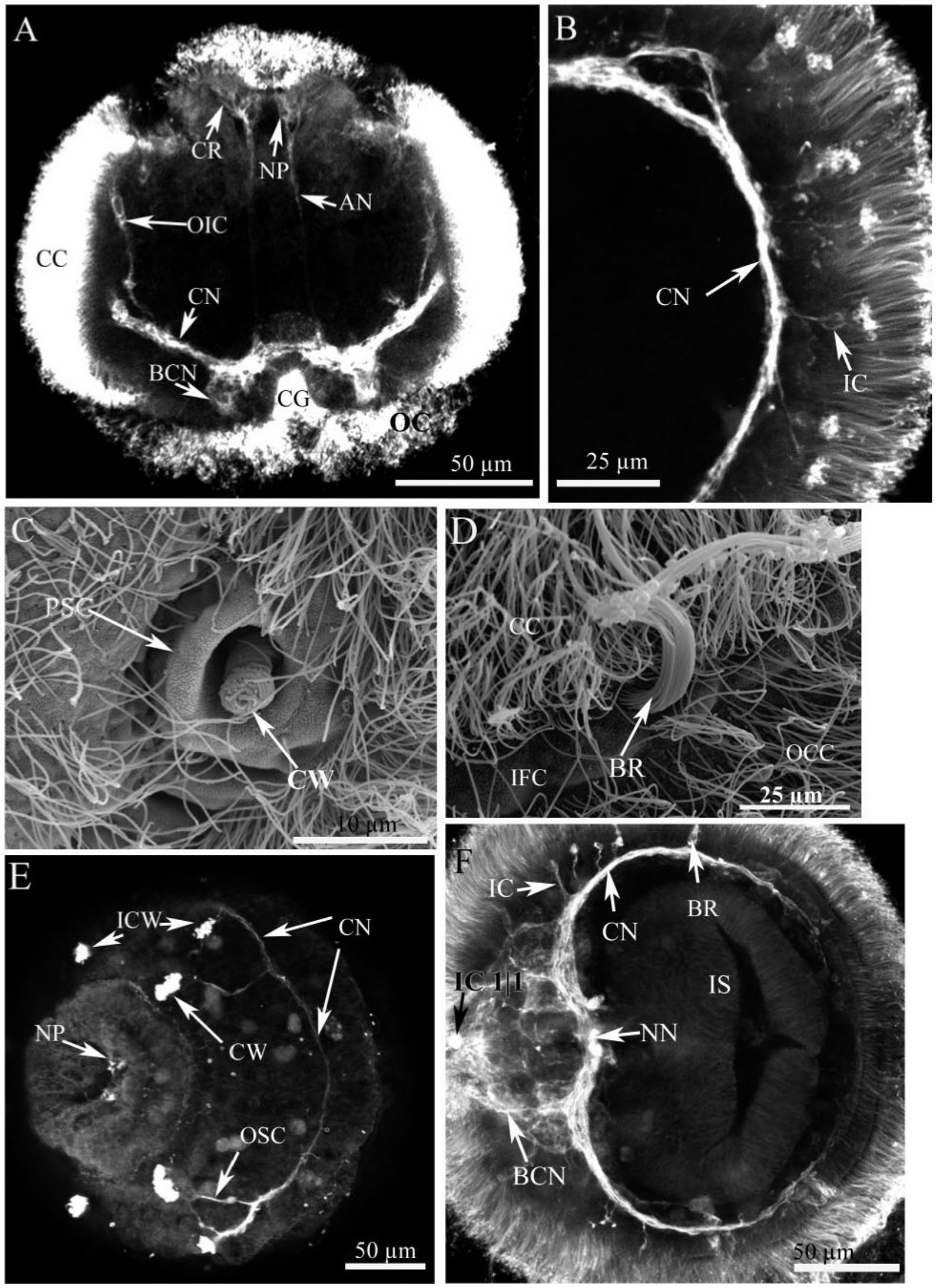
pairs of coronal cells $(1|1,1| 2,3|4,5| 6,7|8,10| 11$, and 13114) within the plane of the coronal nerve ring (Fig. 2B). As in Membranipora larvae, serotonin is mainly found within the nerve nodule, coronal nerve ring, and paraxial nerve cords (NN, CN, and AN, respectively; Appendix Fig. 1C). However, in this species serotonin is also found within the neuronal fibers from the intercoronal eyespots (OIC; Appendix Fig. 1C).

\section{Schizoporella floridana (Superfamily Schizoporelloidea): Nonfeeding Coronate Larva}

In Schizoporella floridana larvae, the potential photosensory neurons have more elaborate ciliary whorls (CW) than those of Celleporaria larvae and are also surrounded by an invaginated pigmented cup (PSC; Fig. 2C). The pigmented cups of the two posterolateral ocelli are derived from the surrounding supracoronal cell layer. Other sensory cell types with modified ciliary tufts are the so-called balancer cells (BR) that are positioned on right and left sides of the larval body within the undifferentiated infracoronal cell region (IFC; Fig. 2D). The bundles of cilia of the balancers cells are much longer than the cilia of the surrounding coronal and oral ciliated cells. Although balancer cells do not bear compound cilia, their ciliary bundles do adhere to one another and occasionally flick while the larva crawls over a substrate.

In the process of clearing the tissue, some larval preparations lost all cilia except the ciliary whorls of the posterolateral ocelli and the tufts of two pairs of bilaterally symmetrical intercoronal cells ( $2 / 3$ and $7 \mid 8$; Fig. 2E). These preparations allowed the full length of the coronal nerve ring $(\mathrm{CN})$ to be visualized, including the thin portion in the posterior half of the larva where it connects with the nerve fibers from the posterolateral ocelli (OSC; Fig. 2E). The thin region of the coronal nerve ring is due to comparatively fewer neuronal fibers in the posterior portion of the larva. This is likely the result of all neuronal fibers from intercoronal cells and ocelli taking unidirectional paths toward the nerve nodule. This species also has an ocellus positioned between the first pair of coronal cells; unlike the previous ocelli, however, its ciliary whorl points in the oral direction (Fig. 2F). In the anterior half of the larva, the coronal nerve ring receives neuronal inputs from the balancer neurons, whose cell bodies are larger than those of the nearby intercoronal cells (BR and IC, respectively; Fig. 2F). As in Celleporaria larvae, the fibers of the coronal nerve ring of Schizoporella merge into the nerve nodule with fibers from intercoronal cells positioned at $112(\mathrm{BCN}$; Fig. 2F) and many other neuronal fibers from sensory cells that border the ciliated groove. There are also numerous neurites positioned around the superior glandular field and the vibratile plume cells, but cell contacts between these surface cells and neurites were not clear. Overall, better resolution of the entire neuromuscular system is shown in dual-labeled specimens for both acetylated $\alpha$-tubulin and fibrous actin (Appendix Fig. 1D).

\section{Bugula spp. (Superfamily Buguloidea): Nonfeeding Buguliform Larvae}

Despite the differences in the relative positions of the apical disc and pyriform complex between buguliform larvae and ascophoran coronate larvae, their nervous system morphologies are more conserved. Buguliform larvae have ocelli and the coronal nerve ring positioned equatorially; similar to ascophoran coronate larvae, the intercoronal cell patterns tend to be species-specific.

Figure 2. The nervous systems of the nonfeeding coronate larvae of Celleporaria sherryae (A and B) and Schizoporella floridana (C-F). (A) Frontal z-projection of the larva of $C$. sherryae labeled with acetylated $\alpha$-tubulin. The neural plate cells (NP) form left and right cell masses that are contacted by neurites from the surrounding ciliated ray cells (CR). Each neuronal cell mass merges into a paraxial nerve cord (AN) that joins with the nerve nodule on the oral side of the larva. Sensory neurons that border the ciliated groove (CG) have neurites that merge into the border cell nerves $(\mathrm{BCN})$ that also merge with the nerve nodule. The coronal nerve ring $(\mathrm{CN})$ receives neuronal fibers from sensory neurons located between coronal cells (OIC) at both anterolateral and posterolateral aboral regions of the larval surface. (B) Numerous intercoronal sensory neurons (IC) with small ciliated tufts send neural fibers into the coronal nerve ring. (C) Scanning elecron micrograph of one of the two posterolateral ocelli of $S$. floridana larvae with red pigmented cups composed of the surrounding supracoronal cells (PSC). At the base of each cup is a sensory cell with an elaborate tightly coiled whorl of cilia (CW). (D) Other modified multiciliated sensory cells that have longer fused cilia (balancer cells, BR) are found in the undifferentiated infracoronal cell band (IFC). (E) Z-projection of a larva of $S$. floridana labeled for acetylated $\alpha$-tubulin in which most of the cilia except those of the posterolateral ocelli and two paired intercoronal cells were sheared off during tissue clearing. This preparation shows the points where the neurites of the posterolateral ocelli (OSC) and intercoronal cells with large ciliated tufts (ICW) merge with the coronal nerve ring (CN). (F) Z-projection of the oral half of the larva labeled with acetylated $\alpha$-tubulin, showing the numerous nerve fibers that border the ciliated groove (BCN), the vibratile plume, and intercoronal cell 111 (IC 1|1). As also found in $C$. sherryae, numerous intercoronal cells with small ciliated tufts (IC) send fibers into the coronal nerve ring $(\mathrm{CN})$. The cell body of each of the posterolateral balancer cells (BR) also sends fibers into the coronal nerve ring, which becomes thin in the posterior region of the larva around the internal sac (IS). 
The nervous system of both Bugula stolonifera and Bugula neritina consists of ciliated ray cells, neural plate cells, paraxial nerve cords, a nerve nodule, and a coronal nerve ring (Fig. 3A, B). The coronal nerve ring (CN; Fig. $3 \mathrm{~A}, \mathrm{~B})$ receives axonal fibers from the sensory cells of the intercoronal ocelli that are posterolateral in $B$. neritina and both posterolateral and anterolateral in B. stolonifera (OIC; Fig. 3A, B). Several other intercoronal cells are positioned at the aboral and oral poles as well as equatorially on the surface of the larvae. Wherever these sensory cell types occur on the larval surface, their axonal fibers usually take the shortest path to the coronal nerve ring. Consistent with
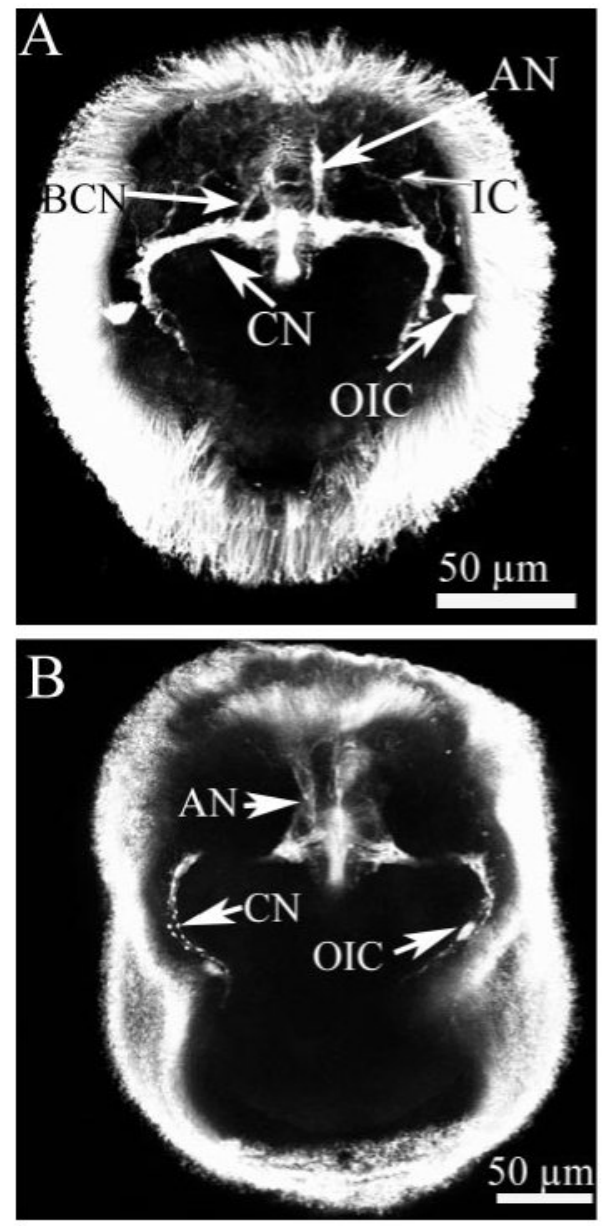

Figure 3. The nervous systems of the nonfeeding buguliform larvae of Bugula stolonifera (A) and Bugula neritina (B) labeled with acetylated $\alpha$-tubulin. Although obscured by the heavily ciliated coronal cells, intercoronal cells similar in position to those of other coronate larval forms are present in both species (see Santagata and Zimmer, 2000; Santagata, 2008). (A) Z-projection of internal frontal sections, showing the paraxial nerve cords (AN), coronal nerve ring $(\mathrm{CN})$, border cell nerves $(\mathrm{BCN})$, and posterolateral ocelli (OIC). This species also has a pair of anterolateral ocelli, the nerve fibers of which are visible (IC), and the position of which corresponds to the intercoronal position 112 of ascophoran coronate larval forms. (B) Similar neuroanatomical features are found in B. neritina, but the main ocelli are posterolateral. the results from other gymnolaemate larvae, two rows of sensory neurons border the ciliated groove and their axonal fibers form a nerve cord that enters the nerve nodule $(\mathrm{BCN}$; Fig. 3A). Dual-labeled specimens of these larvae for both acetylated $\alpha$-tubulin and fibrous actin yield the most informative reconstructions of their neuromuscular systems (Appendix Fig. 1E, F). These preparations of Bugula larvae (and also of the previously mentioned larval forms) show how the nervous system is split into bilaterally symmetrical halves. Neuronal projections from the ciliated ray cells make only ipsilateral contact with the cell bodies of the neural plate cells (CR and NP, respectively; Appendix Fig. $1 \mathrm{E})$ and collectively the only integration center for all sensory inputs is the nerve nodule (NN; Appendix Fig. 1F).

\section{Class Gymnolaemata: Order Ctenostomatida}

Amathia vidovici and Bowerbankia maxima (Superfamily Vesicularioidea): Nonfeeding Vesiculariform Larvae

Compared to the coronate larvae of ascophoran bryozoans, vesiculariform larvae are elongated in the aboral-oral axis, and the positions of the paraxial nerve cords and nerve nodule (Fig. 4A) reflect these differences. Similar to the previous results, acetylated $\alpha$-tubulin labels all neuronal and ciliated cell types. One structural difference is the presence of an aboral neuromuscular ring (AON; Fig. 4B). Larvae of Amathia vidovici have a small apical disc (AD; Fig. 4A), and coronal cells cover most of the larval surface, but the ciliary tufts of intercoronal cells (IC) are easily discerned between adjacent coronal cells (Fig. 4B). Dividing the larval body into aboral (forward), equatorial, and oral (aft) regions, the positions of these sensory neurons are relatively equally distributed (Fig. 4C). The apical dise contains at least four cell types. About 20 neural plate cells (NP) form a bean-like structure in the center of the apical disc (Fig. 4D); these cells are surrounded by a ring of ciliated ray cells that have fibers that contact the neural plate cell bodies (CR; Fig. 4D). Other putative neuronal-like or supportive cell types within the apical disc that are described only for this species (inner and marginal spoke cells, see Zimmer and Woollacott, 1993) are not definitively discriminated from the neural plate cells by acetylated $\alpha$-tubulin labeling. However, the groups of cells that merge into the paraxial nerve cords are more substantial in Amathia larvae than in other species, and this may be due to the presence of supporting glial-like cell types (Fig. 4D).

Bowerbankia maxima colonies produce a nonfeeding vesiculariform larva with features similar to those of Amathia larvae. All intercoronal neurons, whether they are positioned fore, equatorially, or aft, project a single neuronal fiber that enters the coronal ring nerve (ICF and CN; Fig. 4E). Some small differences in this genus include the bowed shape of the paraxial nerve cords, and the position and number of intercoronal cells on the larval surface. This 
species also exhibits numerous spoke-like ciliated ray cells (CR; Fig. 4F) that have fine neuronal fibers that make ipsilateral contact with the cell bodies of the neural plate cells (NP; Fig. 4F). As in Amathia larvae, Bowerbankia larvae have two patches of sensory neurons (juxtapapillary cells) that border the ciliated groove and send neuronal fibers into a main nerve cord (JPN; Fig. 4G) that merges with the nerve nodule (NN; Fig. 4G).

\section{Aeverrillia setigera (Superfamily Aeverrillioidea):} Nonfeeding Larva

The apical disc in this species contains both neural plate cells and ciliated ray cells with characteristics similar to those in previously described species. A clear coronal nerve ring $(\mathrm{CN}$; Fig. 5A) merges into a prominent nerve nodule positioned near the elongate ciliated oral groove present in this species. Ciliated sensory neurons similar to the intercoronal neurons of other gymnolaemate species are present; however, there a few differences in their position. Most if not all of these neurons are positioned within the aboral half of the larval surface between the coronal and oral ciliated cell regions. The ciliated apices of these cells are never found between adjacent coronal cells, and judging from the arrangement of the surrounding cell types, these neurons must be considered infracoronal sensory neurons (IFC; Fig. 4A). Another pair of sensory neurons has their ciliated apices within the supracoronal region (OSC; Fig. 5A) much like the eyespots or ocelli of ascophoran larvae, but they lack any surrounding pigmented tissue or cups.

\section{Nolella stipata (Superfamily Victorelloidea): Nonfeeding Larva}

As described in Santagata (2008), this species does not have any definitive cell types that can be classified as coronate or oral ciliated cells. There are sensory neurons with morphology and position similar to the infracoronal cells and intercoronal neurons previously discussed. However, these sensory neurons are found within aboral (forward), equatorial, and oral (aft) regions (IMC; Fig. 5B, C) between a uniform ciliated epithelium (MC; Fig. 5C). Interestingly, Nolella larvae lack neural plate cells and paraxial nerve cords, but they do possess ciliated cells within the apical disc that are similar to the ciliated ray cells of other species. On the larval surface, all of the sensory neurons with small ciliated tufts merge into a nerve ring with a nerve nodule positioned near a small ciliated pit on the oral side of the larva. Also, the aboral half of the larval surface opposite the nerve nodule is sparsely innervated (Fig. 5C).

\section{Class Stenolaemata: Order Cyclostomata}

\section{Crisia elongata (Family Crisinidae): Nonfeeding Larva}

The larval nervous system of Crisia consists of a series of radially positioned neurons (IMC; Fig. 5D) whose apical tufts are dispersed amongst the uniform field of multiciliated cells that cover the larval surface. Although not as fiber-rich as those in other species, these neurons do merge into a thin equatorial nerve ring (NR; Fig. 5D). A nerve nodule is lacking in this species, as well as any ciliated groove or pit. An apical disc is also lacking, but there are some ciliated cells with immotile cilia located near what would be the apical disc if it were present. The homology between these cells and the ciliated ray cells found in other morphological grades of bryozoan larvae is unclear.

\section{Discussion}

\section{Feeding versus nonfeeding larval forms}

Elements of the bryozoan larval nervous system common to both feeding and (most) nonfeeding forms are an apical disc composed of bipolar sensory/motor neurons; paraxial nerve cords; a nerve nodule (or plexus, sometimes referred to as a lateral commissure, see Wanninger et al., 2005a); a nerve ring; and a series of bipolar sensory/motor neurons that lead into the nerve ring (Fig. 6A-D). Particular to the cyphonautes form are nerves that underlie feeding-related structures such as the ciliated ridges and gut. Previously, it has been demonstrated that marine bryozoans exhibit a wide variety of nonfeeding larval types supportive of numerous combinations of anatomical traits (Zimmer and Woollacott, 1977a; Santagata, 2008). Without the functional demands of feeding in the plankton, the nervous systems of nonfeeding bryozoan larvae have either diversified the structure and function of ciliated sensory neurons or simplified the nervous system within particular lineages, likely due to evolutionary loss. One obvious difference between the sense organs of feeding and nonfeeding larval types is the expansion of the sensory neurons within the apical disc. To some degree the enlargement of the apical disc in several nonfeeding larval forms is due to the addition of undifferentiated cell types that contribute to the polypide after metamorphosis. However, the apical morphology of the ciliated ray cells (neurons) ranges from simple bean shapes to elongate strips, and in some species the ray cells bifurcate like a sensory dendrite (Santagata and Zimmer, 2000; Hippopodina feegensis, data of Santagata within Temkin and Zimmer, 2002). The neurites from the ciliated ray cells that make contact with the neural plate cells are elongated due to the more internalized position of the neural plate cell bodies in nonfeeding bryozoan larval forms. Similar differences can be observed in the expansion (or loss) of the ciliated groove and the sensory neurons that border it. These trends in the structure and function of the nervous system are mirrored in the larval musculature as well as in the ciliated cells responsible for propulsion (see Santagata, 2008), although the morphological changes in the nervous system are more conserved. 

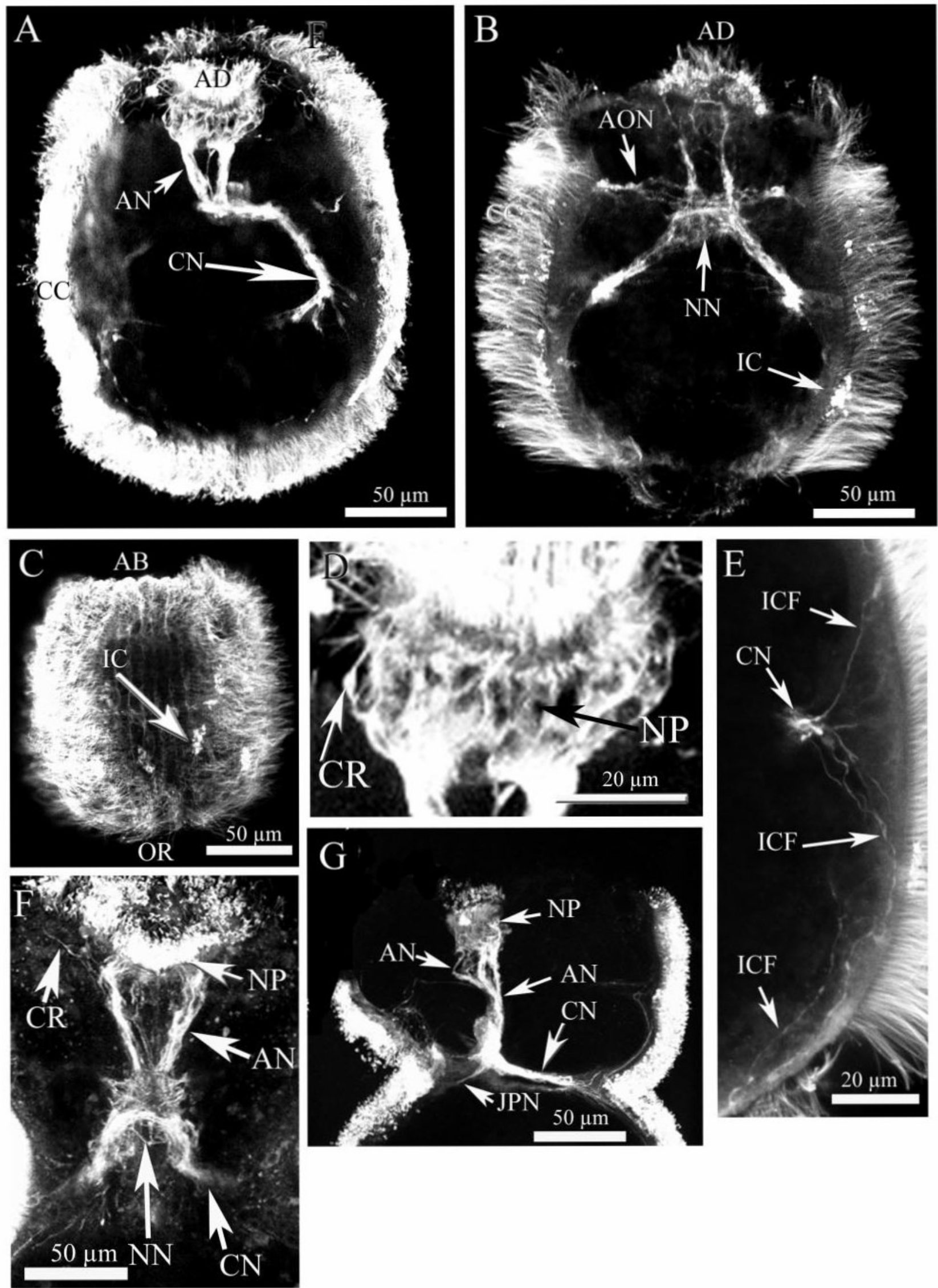


\section{Evolutionary trends in the larval nervous system}

Among all extant forms of bryozoans, paleontological, morphological, and molecular phylogenetic evidence suggests that the ctenostome bryozoans are basal to both the cyclostome and cheilostome grades (Taylor, 1990; Dick et al., 2000; Todd, 2000). The diverse suite of larval traits expressed by basal ctenostomes makes it difficult to absolutely assess the polarity of morphological transitions, especially among feeding structures (Zimmer and Reed, 1994; Santagata, 2008). Overall, aspects of cellular homology are best compared among nonfeeding larval forms (see Tables 1 and 2). The simplified form of cyclostome larvae is best attributed to evolutionary loss, particularly in their lack of an apical organ and nerve nodule. Despite the lack of the neural plate cells and associated nerve cords in Nolella stipata larvae, the nervous system of this species exhibits a greater level of complexity that that of Crisia larvae. Due to the lack of distinctive morphological characteristics of the surrounding multiciliated cells in comparison to the coronal cells of other species, the cellular classification of the equatorial band of sensory neurons (ciliated tuft cells) in Nolella larvae cannot be definitively applied. However, since a nearly identical band of sensory neurons is present in Aeverrillia larvae within the infracoronal zone, it is likely that the equatorial band of sensory neurons in Nolella larvae share this classification. Interestingly, possession of an infracoronal bias in the position of most sensory neurons on the larval surface (and lack of typical intercoronal cells) may be more widely shared among non-vesicularid ctenostome bryozoans. Although more uniform in their ciliary tuft form, the sensory neurons in vesiculariform larvae, like those in the nonfeeding larvae of cheilostome bryozoans, are arranged preferentially in intercoronal positions. Among ascophoran coronate larvae, infracoronal sensory neurons are still common in the form of balancers and sometimes ocelli (data presented here, and in Zimmer and Woollacott, 1989 a, for Watersipora arcuata).

Although differing slightly in position, rows of sensory neurons border the ciliated groove of both vesiculariform larvae (juxtapapillary cells) and feeding and nonfeeding larval forms of cheilostomes (border cells: Stricker et al., 1988b; Zimmer and Woollacott, 1993). Both of these cells types are pressed against the substrate during probing behaviors before metamorphosis and relay stimuli through nerves that join the nerve nodule. Despite the relatively large oral groove present in Aeverrillia larvae, ciliated cells bordering it do not have specialized morphology as compared to those in previous larval forms. Although differing slightly in position to that of other larval forms, the usual structural components of the pyriform complex, such as the superior and inferior glandular fields as well as a row of vibratile plume cells, are pesent in Aeverrillia larvae. However, these structures are reduced in Nolella larvae and completely lacking in cyclostome larvae such as Crisia (Nielsen, 1970).

Perhaps the most elaborate cellular modifications are found in the potential photosensory neurons and their surrounding supporting cells that are often co-opted into producing either shielding pigment or lens-like structures, or both (see Tables 1 and 2). Although most nonfeeding ctenostome larvae are phototactic, few are described as having obvious eyespots. The coronate larvae of Alcyonidium gelatinosum (larva formerly attributed to A. polyoum; see Ryland and Porter, 2006) have a pair of posterolateral balancer cells positioned within the infracoronal region (Barrois, 1877; d'Hondt, 1973) but lack obvious intercoronal cells or pigmented eyespots. Tanganella muelleri larvae possess only isolated intercoronal cells and also lack pigment cup ocelli. Supracoronal ocelli have been observed in Bulbella abscondita larvae (Braem, 1951), and similar supracoronal sensory neurons exist in Aeverrillia setigera larvae, but without any modification of the surrounding tissue. Only in the larvae of Nolella stipata do the surrounding multiciliated cells of its equatorial (likely infracoronal) ciliated tuft cells produce a shielding pigment (see Santagata, 2008).

Nonfeeding larval forms of anascans (Scrupocellaria and Bugula) and ascophoran cheilostomes (Celleporaria,

Figure 4. The nervous systems of the nonfeeding vesiculariform larvae of Amathia vidovici (A-D) and Bowerbankia maxima (E-G). Z-projections of internal fontal sections and surface projections of larvae labeled with acetylated $\alpha$-tubulin. (A) The small apical disc (AD) in A. vidovici contains neuronal cells that contribute to the paraxial nerve cords $(\mathrm{AN})$ that merge into an equatorially positioned nerve nodule (NN, pictured in part $\mathrm{B})$ and the coronal nerve ring (CN). Similar to buguliform larvae, cilia of the coronal cells (CC) cover most of the surface of vesicularifom larvae. $(B, C)$ An aboral nerve ring $(A O N)$ is also found in this species. Intercoronal cells (IC) with small uniform ciliated tufts send fibers into the coronal nerve ring from forward (aboral), equatorial, and aft (oral) positions on the larval surface. (D) The neuronal composition of the apical disc contains additional supporting cell types (inner and marginal spoke cells) that make up the more nodular appearance of the paired cell masses of neural plate cells (NP) and ciliated ray cells (CR). (E, F) Arrangements of sensory cell groups and nerve cords found in the larvae of B. maxima are similar to those of Amathia larvae. Although intercoronal cell positions and fiber tracings (ICF) are not identical to those of $A$. vidovici, the differences are not significant from a functional perspective. (G) Lateral view of the nervous system, showing the nerve cords from the juxtapapillary cells (JPN) that border the ciliated groove. These cell types are also found in Amathia. 

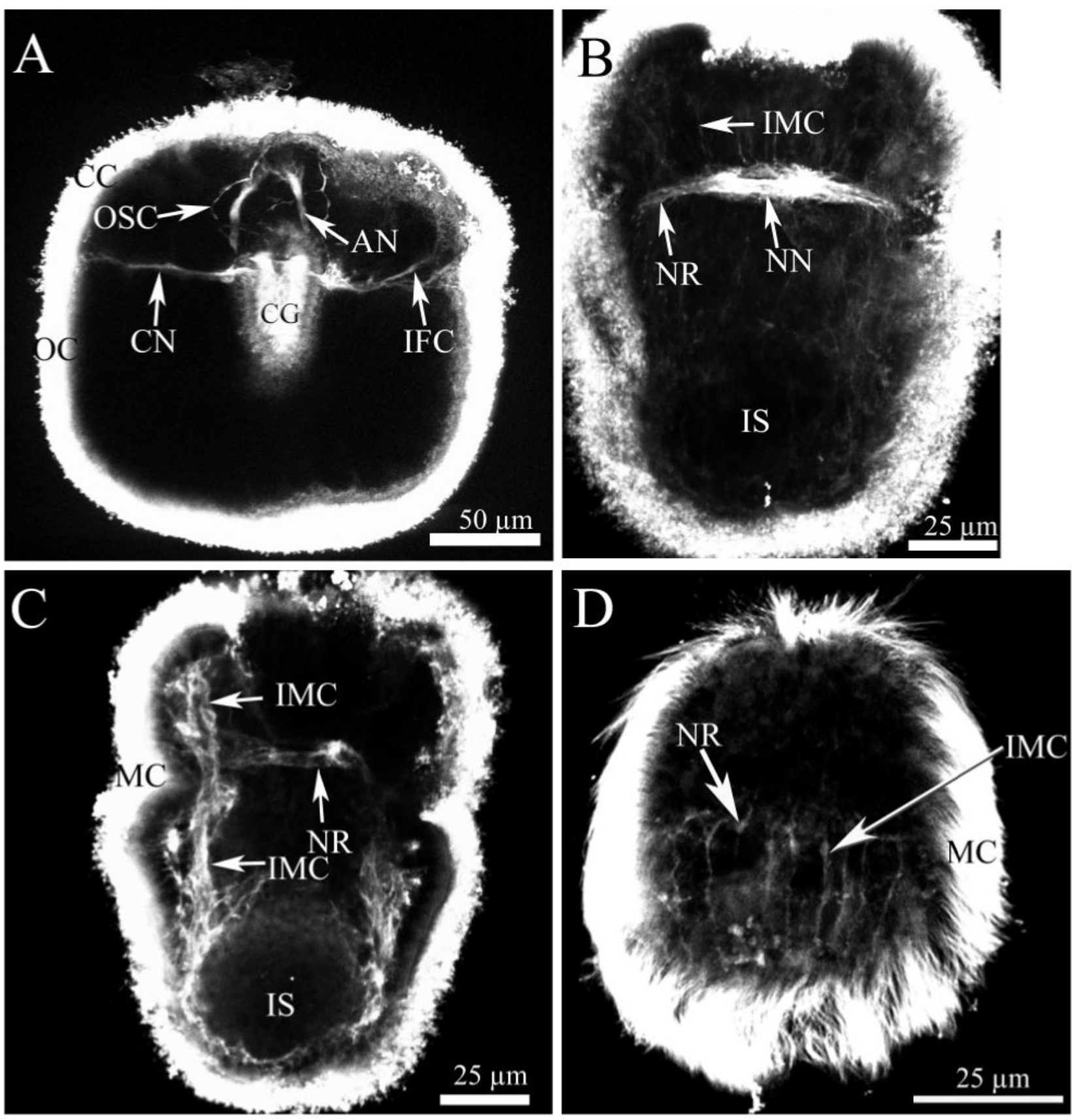

Figure 5. The nervous system of select species of ctenostome and cyclostome bryozoans labeled with acetylated $\alpha$-tubulin. (A) Internal z-projection composed of frontal sections of the larva of Aeverrillia setigera. This larval form is elongate in the aboral-oral axis. As with most other species, neural plate cells and ciliated ray cells in the apical disc are connected to the nerve nodule by paraxial nerve cords (AN). Infracoronal sensory cells (IFC) positioned in an equatorial ring between the coronal cell (CC) and oral ciliated cell (OC) fields on the larval surface send fibers into the coronal nerve ring $(\mathrm{CN})$. A pair of supracoronal sensory cells (OSC) on either side of the apical dise also connects to the coronal nerve ring on lateral sides of the ciliated groove (CG). (B) Neural plate cells and paraxial nerve cords are lacking in the larva of Nolella stipata, although cells similar to the ciliated ray cells are present in the apical disc. A nerve ring and nerve nodule are present (NR and NN) and receive fibers from small ciliated tuft cells (IMC) positioned in forward (aboral), equatorial, and aft (oral) regions of the larval body. (C) Lateral internal view of a Nolella stipata larva, showing the numerous fibers from the small ciliated tuft cells (IMC) that are dispersed over the larval surface among the uniform multiciliated cells (MC). (D) The nervous system of the larva of Crisia elongata is simplified compared to other larval forms. An apical dise is entirely lacking in this species, and all that remains of the larval nervous system are simple ciliated neurons (IMC) dispersed among the hexagonal multiciliated cells on the larval surface. Collectively these simple neurons contribute to a fiber-poor nerve ring (NR). 

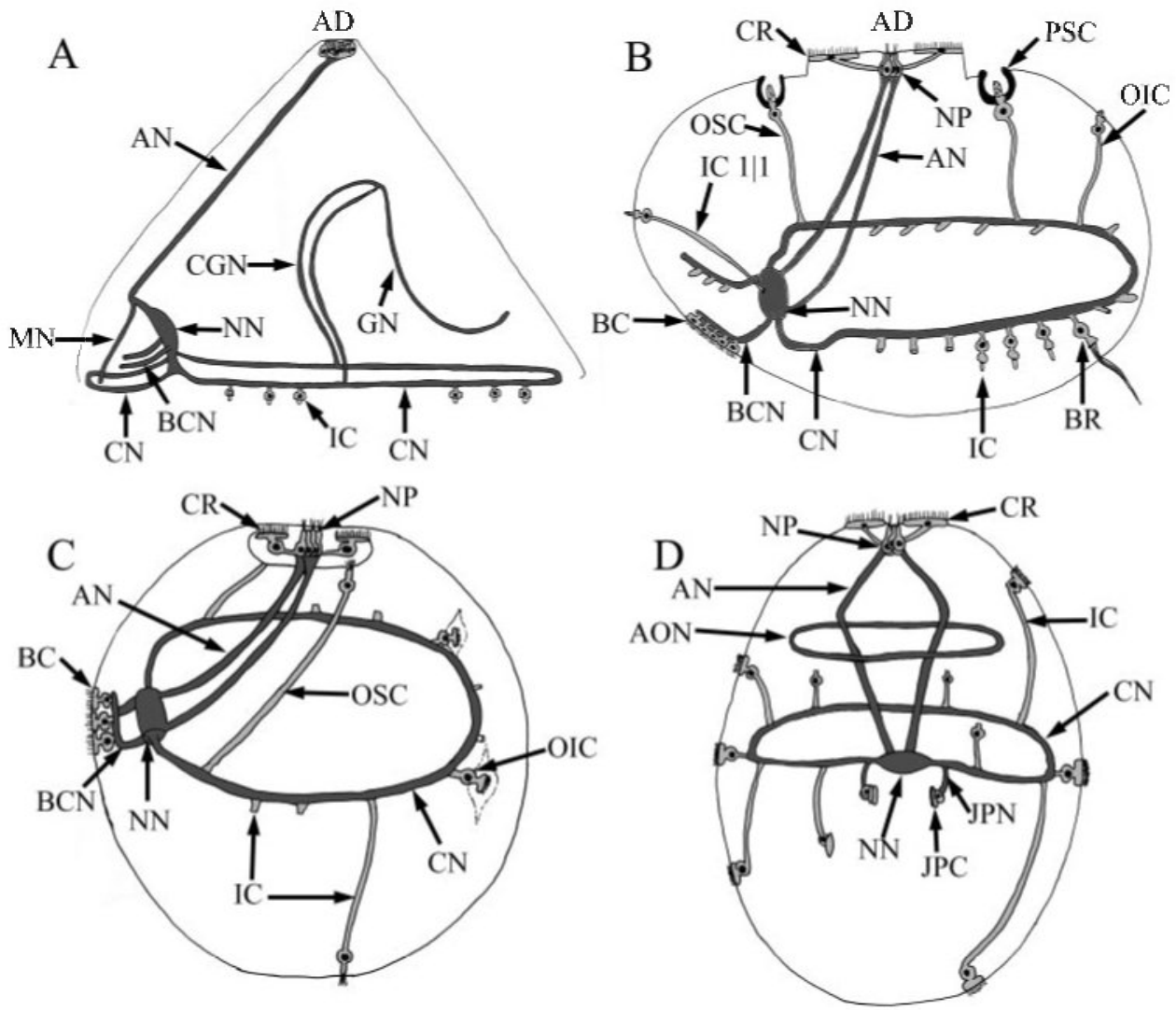

Figure 6. Representations of the larval nervous systems of various bryozoan larval forms based on ultrastructural and immunohistochemical data (see previous figures for additional abbreviations; not drawn to scale). Nerves are colored dark gray, and the neuronal fibers from single cells are colored light gray. (A) Lateral view of the cyphonautes larva of Membranipora membranacea. Although not shown in previous figures, nerves underneath the ciliated ridges also connect with a nerve tract around the gut (GN, additional data from Stricker et al., 1988a, b). (B) Lateral view of a generalized nervous system in ascophoran coronate larvae. Sensory neurons that border the ciliated groove (BC) are more pronounced in this larval type as compared to cyphonautes larvae. Although anterolateral and posterolateral supracoronal ocelli are depicted (OSC), individual species usually possess only one type. The intercoronal cell depicted at position 111 (IC 111) sending a fiber directly into the nerve nodule is not present in all species (additional data gathered from Reed, 1991; Santagata and Zimmer, 2000, Zimmer and Woollacott, 1989a, b; Santagata, 2008). (C) Lateral view of a generalized nervous system in buguliform larvae of cellularioid bryozoans. Although not figured, some species also have an ocellus at intercoronal position 111 as in some ascophoran coronate larvae (additional data gathered from Woollacott and Zimmer, 1972; Zimmer and Woollacott, 1977a; Hughes and Woollacott, 1978, 1980; Reed and Woollacott, 1982; Reed et al., 1988; Santagata and Zimmer, 2000). (D) Oral view of a generalized nervous system in vesculariform larvae such as those found in species of Amathia and Bowerbankia. Note similarity between the border cells (BC) in cheilostome larvae and the juxtapapillary cells (JPC) of vesiculariform larvae (additional data gathered from Reed, 1988; Zimmer and Woollacott, 1993).

Schizoporella, Watersipora, and others) have the most complex types of ocelli. Tightly wound sensory ciliary whorls and deeply invaginated pigmented cups are common among many species and can be infracoronal, intercoronal, or supracoronal in position. Although the precise intercoronal positions of ascophoran coronate larvae are species-specific and vary along with differences in the number of coronal cells, the most common positions for pigment cup ocelli are between the first pair of coronal cells (position 1|1), an anterolateral supracoronal pair near coronal cells 7 and 8 , and a posterolateral supracoronal pair near coronal cells 10 and 11. Surrounding cell types that produce shielding pigment vary within the same genus: Celleporaria brunnea larvae (Santagata and Zimmer, 2000) have supracoronal anterolateral ocelli, but $C$. sherryae larvae have only simple intercoronal eyespots. Regardless of this structural variation, most putative photosensory neurons in ascophoran coronate larvae have their ciliary whorls pointed forward in the direction of swimming. Although some buguliform larval types such as Bugula and Scrupocellaria often have numerous coronal cells, the same relative positions for their intercoronal ocelli are maintained $(1|1,1| 2,7 \mid 8$, and 10111, 
Table 1

Structural diversity of ciliated sensory neurons among select nonfeeding marine bryozoan larvae (cyclostome and ctenostome grades)

\begin{tabular}{|c|c|c|c|c|}
\hline \multirow[b]{2}{*}{ Region of larval body } & \multicolumn{4}{|c|}{ Genus or larval type } \\
\hline & Crisia $^{1}$ & Nolella & Aeverrillia & Vesiculariform $^{2}$ \\
\hline Apical disc & Absent & $\mathrm{CR}$ & $\mathrm{CR}$ and NP & $\mathrm{CR}$ and NP \\
\hline Bordering the oral groove & Absent & Absent & Absent & JPC \\
\hline $\begin{array}{l}\text { Adjacent to propulsive } \\
\text { ciliary fields }\end{array}$ & Simple \& uniform (IMC) & Ciliated tufts (IMC) & Ciliated tufts (SC and IFC) & Ciliated tufts (IC) \\
\hline $\begin{array}{l}\text { Potential photosensory } \\
\text { neurons/Co-option of } \\
\text { surrounding tissue }\end{array}$ & $\begin{array}{l}\text { Subset of IMC?/None \& } \\
\text { lack of shielding } \\
\text { pigment }\end{array}$ & $\begin{array}{l}\text { Likely the equatorial IMC/ } \\
\text { Pigmented MC band }\end{array}$ & $\begin{array}{l}\text { Both } \mathrm{SC} \text { and IFC neurons/ } \\
\text { Coronal cells pigmented }\end{array}$ & $\begin{array}{l}\text { All IC?/None \& lack of } \\
\text { shielding pigment }\end{array}$ \\
\hline
\end{tabular}

${ }^{1}$ Additional data gathered from Nielsen (1970).

${ }^{2}$ Additional data gathered from Reed (1988) and Zimmer and Woollacott (1993).

Abbreviations: ciliated ray cells (CR); infracoronal neurons (IFC); intercoronal neurons (IC); simple multiciliated neurons (IMC); juxtapapillary cells (JPC); simple multiciliated cells on surface of the larva used for propulsion (MC) that cannot be definitively classified as coronal cells (CC) or oral ciliated cells; neural plate cells (NP); supracoronal cells (SC). ? Denotes where the inferred function of particular cell types is unclear based on cell structure and/or larval behavior.

see Woollacott and Zimmer, 1972; Hughes and Woollacott, 1978, 1980; Reed et al., 1988). Even though the intercoronal cells of cyphonautes larvae are inconspicuous, the position of the median nerve of the pyriform complex is likely homologous to the intercoronal cell at position 111 in coronate larvae. Overall, among bryozoan systematic groups, species with typical coronate larval forms that have a 90 degree difference in the orientation of swimming versus crawling (see Santagata, 2008) have the majority of their photosensory structures positioned forward on the larval body (supracoronal and aboral-intercoronal). Conversely, several species that have larvae elongated in the aboral-oral axis and do not exhibit differences in orientation during swimming and crawling behaviors tend to have equatorially positioned photosensory structures (intercoronal and infracoronal, see Fig. 6C, D, and Appendix Fig. 2A, B).

\section{Functional implications based on ultrastructural and immunohistochemical data}

Although these synapses have not been strictly demonstrated for all species, the ultrastructural work on Bowerbankia gracilis (Reed, 1988) and Bugula stolinfera (Reed et al., 1988) larvae shows that there are chemical synapses between the ciliated ray cells and the neural plates cells and between intercoronal cells and adjacent coronal cells. In

Table 2

Structural diversity of ciliated sensory neurons among cheilostome bryozoan larvae.

\begin{tabular}{|c|c|c|c|}
\hline \multirow[b]{2}{*}{ Region of larval body } & \multicolumn{3}{|c|}{ Larval type } \\
\hline & Cyphonautes $^{1}$ & Buguliform $^{2,3}$ & Ascophoran coronate ${ }^{2,4}$ \\
\hline Apical disc & $\mathrm{CR}$ and NP & CR and NP & $\mathrm{CR}$ and $\mathrm{NP}$ \\
\hline Bordering the oral groove & $\mathrm{BC}$ & $\mathrm{BC}$ & $\mathrm{BC}$ \\
\hline Adjacent to propulsive ciliary fields & Ciliated tufts (IC) & $\begin{array}{l}\text { Ciliary whorls (IC) } \\
\text { Ciliated tufts (SC) }\end{array}$ & $\begin{array}{l}\text { Ciliary whorls (SC, IC, IFC) } \\
\text { Ciliated tufts (IC) } \\
\text { BR (IFC) }\end{array}$ \\
\hline $\begin{array}{l}\text { Potential photosensory neurons/Co- } \\
\text { option of surrounding tissue }\end{array}$ & $\begin{array}{l}\text { IC?/Pigmented band of cells near } \\
\text { coronal cells? }\end{array}$ & $\begin{array}{l}\text { Ciliary whorls (IC)/ } \\
\text { Pigmented indentations (CC) }\end{array}$ & $\begin{array}{l}\text { Ciliary whorls (SC, IC, IFC)/ } \\
\text { Pigmented cup (SC, CC, IFC) and } \\
\text { lens-like structures }(\mathrm{SC}, \mathrm{IFC})\end{array}$ \\
\hline
\end{tabular}

${ }^{1}$ Additional data gathered from Stricker et al. (1988a, b).

${ }^{2}$ Additional data gathered from Santagata and Zimmer (2000).

${ }^{3}$ Additional data gathered from Hughes and Woollacott (1978, 1980); Woollacott and Zimmer (1972); Reed et al. (1988).

${ }^{4}$ Additional data gathered from Zimmer and Woollacott (1989a, b).

Abbreviations: Border cells (BC); ? Denotes where the inferred function of particular cell types is unclear based on cell structure and/or larval behavior. See Table 1 for additional abbreviations. 
addition, there are efferent chemical junctions between the coronal cells and the coronal nerve ring, and gap junctions between adjacent coronal cells. Reed et al. (1988) did not detect the axonal fiber projecting from each intercoronal cell or ocellus into the coronal nerve ring, presumably due to their small size. These previous ultrastructural data along with the reconstructions provided here show that bryozoan larvae receive sensory information from numerous radial positions over the larval body, process it in the nerve nodule, and send signals to discrete effector organs such as the musculature or propulsive ciliary fields. Intercoronal cells may receive various types of sensory stimuli, and they directly control the ciliary beat of adjacent coronal cells through shared chemical synapses (Reed, 1988). This interpretation is likely correct and, coupled with the presence of electric junctions between adjacent coronal cells, suggests that localized stimuli from an adjacent portion of the larval surface (other than from the apical disc and pyriform complex) can be quickly transduced and propagated among coronal cells. Furthermore, the spatial integration between the direction of various stimuli and the location of the responding effector organs seems to be hard-wired in bilaterally symmetrical halves of the larval body. Among all morphological grades of marine bryozoan larvae, the cell contacts between sensory cells and their effectors are predominantly ipsilateral. This is supported by the strict rightside or left-side wiring of the connections between ciliated ray cells and neural plate cells as well as between the intercoronal cells and the larval nerve ring (coronal or otherwise). The only region of the larval nervous system where signals from sensory cells on both sides of the larval body, the pyriform complex, and the apical disc can be integrated is the nerve nodule, where more complex synapses are centralized. These anatomical features along with the bidirectional nature of neuronal signals would allow for more complex larval behaviors.

Based on this information, one simple model for how photoklinotaxis is achieved in nonfeeding bryozoan larval types would be that the ciliary beat within the region of the propulsive ciliary field diametrically opposite the photoreceptors exposed to the light stimulus is continually upregulated as the larvae spin and swim forward. This would bias the direction of the larva toward the light until the stimulus crossed the midline of the larval body, after which the receptive and effector sides of the larval surface would be reversed, causing the larva to once again veer toward the light. These occurrences combined with the metachronal beat of cilia would result in directionally biased (spiral) larval paths. Video projections of larval paths during phototactic behaviors support this hypothesis (Santagata, pers. obs.). The switch to photonegative behavior prior to metamorphosis would only require downregulation of effector ciliary beat among the same receptor-effector complex. The only structural constraint for this hypothesis would be that sensory and motor signals be transduced at numerous radial positions around the larval body. Despite the anatomical differences among distant evolutionary groups of bryozoans, all species that exhibit phototactic behaviors possess the necessary receptor-effector systems to achieve this transduction. Furthermore, it has previously been shown that serotonin shortens (also forces swimming) and dopamine extends (also forces crawling behavior) the duration of larval phototactic behaviors in Bugula neritina (Pires and Woollacott, 1997; Shimizu et al., 2000). Immunohistochemical evidence presented here and in previous publications shows that serotonin, catecholamines, and FMRFamide are collectively present within select neural plate cells, putative photosensory neurons, the nerve nodule, coronal nerve ring, balancer cells, and the nerves that border the ciliated groove in feeding and nonfeeding marine bryozoan larvae (Pires and Woollacott, 1997; Shimizu et al., 2000; Wanninger et al., 2005a). In species with nonfeeding larvae that, like Crisia, show a largely ambiguous response to light stimuli, complex receptor-effector integration is not necessary, and this lack is reflected in the overall degenerate state of their nervous system. Cyclostome larval nervous systems are therefore functionally convergent with the sensory-motor systems present in some sponge and planula larval types (Woollacott, 1990; Leys and Degnan, 2001; Maldonado et al., 2003; Nordstrom et al., 2003).

Both feeding and nonfeeding larval forms have sensory neurons that receive mechanical and chemical stimuli during active settlement behaviors before finding an appropriate site to metamorphose. Collectively, most of these sensory neurons are the cells that border the ciliated groove, intercoronal cells in positions $1 / 1$ and $1 / 2$, and the balancer cells. Previous work that used fluorescent mitochondrial probes to examine the metabolic activity of these cell types prior to metamorphosis showed that they were most active during crawling behaviors (Santagata and Zimmer, 2000). Although also metabolically active and generally inferred as a sense organ, the vibratile plume cells and the nerve nodule were not found here or previously (Reed et al., 1988) to have a direct neuronal connection. Although numerous neurites underlie the vibratile plume cells, the large bundles of motile cilia of these cells may only facilitate chemical receptors by creating ciliary currents rather than having a direct sensory role (analogous to antennule flicking by crustaceans; see Koehl, 2006).

\section{Evolution of the nervous system within the Lophotrochozoa}

Apical sense organs (and/or the apical ganglion) are a common feature of many marine invertebrate larval forms (Nielsen, 2005). Beyond the traits that are clearly common 
to both lophotrochozoans and deteurostomes (i.e., a bilaterally symmetrical mass of bipolar sensory and other associated ganglion-like cell types), few morphological aspects of the apical organ and nervous system of bryozoan larval forms link them to phoronids, brachiopods, or other lophotrochozoans. Most phylogenetic interpretation of larval nervous systems is based (almost by default due to the lack of other ubiquitous probes) on the neuronal cell types and fibers recognized by a commonly available antibody to serotonin (Hay-Schmidt, 2000; Friedrich et al., 2002). The larval apical organs of chitons and entoprocts include a centrally localized group of eight flask-shaped cells and additional peripheral cells that send fibers into a central neuropil (Voronezhskaya et al., 2002; Wanninger et al., 2007). The number of serotonergic cell types in the larval apical organs of gastropods varies depending upon systematic group, but having two serotonergic cell types is likely a shared feature (Page and Parries, 2000; Page, 2002). Examples in which such cell groups are lacking are found within the larvae of sipunculids (Wanninger et al., 2005b) and echiurans (Hessling and Westheide, 2002) and have been interpreted as independent losses or the result of truncated larval developmental programs (see Wanninger et al., 2007). Despite deep evolutionary conservation of serotonin as a signal molecule among metazoans (Hay-Schmidt, 2000), failure of the available serotonin antibody to label all serotonergic cell types in particular evolutionary lineages cannot be ruled out. However, despite many morphological differences among the larval nervous systems of the "lophophorates" and those of annelids and molluscs, phoronids and brachiopods also have numerous serotonergic cells, consisting of bipolar sensory cells and additional peripheral cells, in their apical organs (Santagata, 2002; Santagata and Zimmer, 2002). The cyphonautes larva of Membranipora membranacea and the nonfeeding larva of Bugula neritina each have a single pair of serotonergic neural plate cells within their respective apical discs (this paper and Pires and Woollacott, 1997). Results from other nonfeeding larval forms of cheilostomes agree with these findings and differ only to the degree that the neural plate cells are labeled by the antibody (see Appendix Fig. 1C) due to the tissue properties of different species. Therefore the serotonergic nervous system of cyphonautes and ascophoran coronate larvae of cheilostomes are essentially identical (except for the elaboration of particular sensory structures) and are not heterogenic as described by Wanninger et al. (2005a). The lack of a central, pyramidal-shaped neuropil beneath the apical organ and the limited serotonergic components of the nervous system within bryozoan larvae suggest that the state of the bryozoan nervous system may be a derived condition among lophotrochozoans. However, considering the serotonergic nature of two neural plate cells and their connections with the overlying ciliated ray cells, it is plausible that this cellular arrangement is derived from a trochophore-like ancestor whose apical organ possessed a central group of serotonergic neurons that received sensory inputs from a surrounding group of multiciliated cells.

One additional theme among lophotrochozoan nervous systems is the repeated heterochronic shifts that occur with respect to the separation or integration of larval and juvenile tissues (Santagata and Zimmer, 2002). Overall, the larvae of annelids, molluscs, and sipunculids show a general trend toward developing the juvenile (post-trochal) nervous system precociously and integrating it with that of the larval (pre-trochal) nervous system. Similar features were noted for the creeping larva of the entoproct Loxosomella murmanica (Wanninger et al., 2007). Phoronids and brachiopods have different levels of functional and developmental integration of their larval and juvenile tissues among species (detailed in Santagata and Zimmer, 2002), but in general, the juvenile neuromuscular system is developed precociously within the body of the larva, and neuronal connections are shared between the larval nervous system (apical ganglion and tentacular nerve rings) and the juvenile neuromuscular system. Contrary to these examples, the tissues that eventually form the polypide and cystid of bryozoan ancestrulae are largely undifferentiated in all bryozoan larval forms except for those of phylactolaemates (see Franzén and Sensenbaugh, 1983). As a consequence, metamorphosis requires significantly more time to produce a functional feeding juvenile in marine bryozoans than in many other phyla (Zimmer and Woollacott, 1977b; Hadfield et al., 2001). The limited serotonergic nervous system in bryozoan larvae may be linked to the lack of functional or structural integration of the juvenile tissue during larval life. It is reasonable to hypothesize that differentiation of juvenile tissues within the body of the larva would necessitate a more complex "larval" neuromuscular system to achieve the necessary rapid rearrangements at metamorphosis. Testing this hypothesis requires a more detailed analysis of larval and juvenile neuromuscular systems among a group of species with incremental differences in the integration of larval and juvenile tissues.

Bryozoans provide a unique opportunity to study the functional and evolutionary implications of larval neuromuscular systems within the diverse array of forms present within the Lophotrochozoa. Here (and in Santagata, 2008), I demonstrate that regardless of the morphological divergence in larval anatomy that is found among marine bryozoans, the larval nervous system and its major effector organs (musculature and ciliary fields) are largely molded on the basis of the functional demands of feeding, ciliary propulsion, phototactic behaviors, and substrate exploration. When we consider the evolutionary relationships among the morphological grades of marine bryozoans, it is apparent that lineages within the ctenostomes and cheilo- 
stomes are independently evolving larval traits that convey both a greater range of sensory abilities and an increased propulsive capacity. The shared absence or simplification of specific neuromuscular structures (such as in Crisia and Nolella larvae) is likely the result of convergent evolutionary loss. Extracting additional evolutionary information from bryozoan larval anatomy requires data from more systematic groups and the production of other ubiquitous cellular probes. Furthermore, since many of the conserved developmental genes observed throughout the Metazoa are involved in the specification of neuronal and muscle cell types (such as Pou and Lim genes; Larroux et al., 2006), exploring the expression of these genes in a developmental system in which the juvenile neuromuscular system is differentiated only after larval life would be an advantageous comparison to other bilaterian larval types that develop the juvenile neuromuscular system during larval life.

\section{Acknowledgments}

Most of this project was completed while the author was a postdoctoral fellow at the Smithsonian Marine Station at Fort Pierce, Florida. I am especially grateful to the staff of the Smithsonian Marine Station for their help in field collection and maintenance of the station's facilities despite occasional adverse weather conditions. Some of this work was completed while the author was an independent researcher at Friday Harbor Laboratories, Washington. I thank the Center of Cell Dynamics for generously allowing me access to their Bio-Rad Radiance confocal microscope. In particular, I thank Michael Baltzley, William (Woody) Lee, Valerie Paul, Julie Piraino, Sherry Reed, Hugh Reichardt, Mary Rice, Raphael Ritson-Williams, Richard Strathmann, Scott Schwinge, Aimee Urata, Judy Winston, and Russel Zimmer. This research was funded by a Smithsonian postdoctoral fellowship granted to the author and is contribution number 726 of the Smithsonian Marine Station at Fort Pierce, Florida.

\section{Literature Cited}

Barrois, J. 1877. Recherches sur l'embryologie des Bryozoaires (Memoire sur l'embryologie des Bryozoaires). Trav. Stn. Zool. Wimereux 1: $1-305$.

Bishop, C. D., and R. D. Burke. 2007. Ontogeny of the holothurian larval nervous system: evolution of larval forms. Dev. Genes Evol. 217: 585-592.

Braem, F. 1951. Über Victorella und einige ihrer nächsten Verwandten, sowie über die Bryozoenfauna des Ryck bei Greifswald. Zoologica 102: $1-59$.

Braubach, O. R., A. J. G. Dickinson, C. C. E. Evans, and R. P. Croll. 2006. Neural control of the velum in larvae of the gastropod, Ilyanassa obsoleta. J. Exp. Biol. 209: 4676-4689.

Cartwright, P., and A. Collins. 2007. Fossils and phylogenies: integrating multiple lines of evidence to investigate the origin of early major metazoan lineages. Integr. Comp. Biol. 47: 744-751.
Chia, F. S., J. Buckland-Nicks, and C. M. Young. 1984. Locomotion of marine invertebrate larvae: a review. Can. J. Zool. 62: 1205-1222.

Cohen, B. L., and A. Weydmann. 2005. Molecular evidence that phoronids are a subtaxon of brachiopods (Brachiopoda: Phoronata) and that genetic divergence of metazoan phyla began long before the early Cambrian. Org. Divers. Evol. 5: 253-273.

d'Hondt, J. L. 1973. Étude anatomique, histologique, et cytologique de la larve d'Alcyonidium polyoum (Hassall, 1841), Bryozoaire Cténostome. Arch. Zool. Exp. Gen. 114: 537-602.

Dick M., J. R. Freeland, L. P. Williams, and M. Coggeshall-Burr. 2000. Use of $16 \mathrm{~S}$ mitochondrial ribosomal DNA sequences to investigate sister-group relationships among gymnolaemate bryozoans. Pp. 197210 in Proceedings of the 11th International Bryozoology Association Conference, A. Herrera-Cubilla and J. B. C. Jackson, eds. Smithsonian Tropical Research Institute, Republic of Panama.

Emlet, R. B. 1994. Body form and patterns of ciliation in nonfeeding larvae of echinoderms: functional solutions to swimming in the plankton. Am. Zool. 34: 570-585.

Franzén, A., and T. Sensenbaugh. 1983. Fine structure of the apical plate in the larva of the fresh-water bryozoan Plumatella fungosa (Pallas) (Bryozoa: Phylactolaemata). Zoomorphology 102: 87-98.

Friedrich, S., A. Wanninger, M. Bruckner, and G. Haszprunar. 2002. Neurogenesis in the mossy chiton, Mopalia muscosa (Gould) (Polyplacophora): evidence against molluscan metamerism. J. Morphol. 253: $109-117$.

Gosse, P. H. 1855. Notes of some new or little-known marine animals. Ann. Mag. Nat. Hist. ser. 2 16: 27-36.

Hadfield, M. G., E. J. Carpizo-Ituarte, K. del Carmen, and B. T. Nedved. 2001. Metamorphic competence, a major adaptive convergence in marine invertebrate larvae. Am. Zool. 41: 1123-1131.

Halanych, K. M. 2004. The new view of animal phylogeny. Annu. Rev. Ecol. Evol. Syst. 35: 229-256.

Harrison, F. W. 2002. A note from the editor. J. Morphol. 252: 1.

Hay-Schmidt, A. 2000. The evolution of the serotonergic nervous system. Proc. R. Soc. Lond B Biol. Sci. 267: 1071-1079.

Heller, C. 1867. Die Bryozoen des Adriatischen Meeres. Verh. Zool-bot. Ges. Wien 17: 77-136.

Hessling, R., and W. Westheide. 2002. Are Echiura derived from a segmented ancestor? Immunohistochemical analysis of the nervous system in developmental stages of Bonellia viridis. J. Morphol. 252: $100-113$.

Heyland, A., and L. L. Moroz. 2006. Signaling mechanisms underlying metamorphic transitions in animals. Integr: Comp. Biol. 46: 743-759.

Hinks, T. H. 1887. The Polyzoa of the Adriatic: a supplement to Professor Heller's "Die Bryozoen des Adriatischen Meeres," 1867, Pt. 2. Ann. Mag. Nat. Hist. 19: 302-316.

Hughes, R. L., Jr., and R. M. Woollacott. 1978. Ultrastructure of the potential photoreceptor organs in the larva of Scrupocellaria bertholetti (Bryozoa). Zoomorphologie 91: 225-234.

Hughes, R. N., and R. M. Woollacott. 1980. Photoreceptors of bryozoan larvae (Cheilostomata, Cellularioidea). Zool. Scr. 9: 129-138.

Jebram, D. H. A. 1992. The polyphyletic origin of the Cheilostomata (Bryozoa). Z. Zool. Syst. Evolutionsforsch.. 30: 46-52.

Kempf, S. C., and L. R. Page. 2005. Anti-tubulin labeling reveals ampullary neuron ciliary bundles in opisthobranch larvae and a new putative neural structure associated with the apical ganglion. Biol. Bull. 208: $169-182$.

Koehl, M. A. R. 2006. The fluid mechanics of arthropod sniffing in turbulent odor plumes. Chem. Senses 31: 93-105.

Larroux, C., B. Fahey, D. Liubicich, V. F. Hinman, M. Gauthier, M. Gongora, K. Green, G. Worheide, S. P. Leys, and B. M. Degnan. 
2006. Developmental expression of transeription factor genes in a demosponge: insights into the origin of metazoan multicellularity. Evol. Dev. 8: 150-173.

Leys, S. P., and B. M. Degnan. 2001. Cytological basis of photoresponsive behavior in a sponge larva. Biol. Bull. 201: 323-338.

Linnaeus, C. 1758. Systema Naturae, 10th ed., vol. 1. Stockholm.

Linnaeus, C. 1767. Systema Naturae, 12th ed. L. Salvii, Holmiae. (Stockholm).

Maldonado, M., M. Durfort, D. A. McCarthy, and C. M. Young. 2003. The cellular basis of photobehavior in the tufted parenchymella larva of demosponges. Mar: Biol. 143: 427-441.

Milne-Edwards, H. 1838. Mémoire sur les Crisies, les Hornères et plusieurs autres polypes vivans ou fossiles dont l'organisation est analogue à celle des Tubulipores. Ann. Sci. Nat. Zool. ser. 2 9: 193238.

Nielsen, C. 1970. On metamorphosis and ancestrula formation in cyclostomatous bryozoans. Ophelia 7: 217-256.

Nielsen, C. 2005. Larval and adult brains. Evol. Dev. 7: 483-489.

Nordstrom, K., R. Wallen, J. Seymour, and D. Nilsson. 2003. A simple visual system without neurons in jellyfish larvae. Proc. $R$. Soc. Lond. B Biol. Sci. 270: 2349-2354.

Osburn, R. C. 1914. Bryozoa of the Tortugas Islands. Carnegie. Inst. Wash. 182: 181-222.

Page, L. R. 2002. Comparative strueture of the larval apical sensory organ in gastropods and hypotheses about function and developmental evolution. Invertebr: Reprod. Dev. 41: 193-200.

Page, L. R., and S. C. Parries. 2000. Comparative study of the apical ganglion in planktotrophic caenogastropod larvae: ultrastructure and immunoreactivity to serotonin. J. Comp. Neurol. 418: 383-401.

Pires, A., and R. M. Woollacott. 1997. Serotonin and dopamine have opposite effects on phototaxis in larvae of the bryozoan Bugula neritina. Biol. Bull. 192: 399-409.

Reed, C. G. 1988. Organization of the nervous system and sensory organs in the larva of the marine bryozoan Bowerbankia gracilis (Ctenostomata, Vesiculariidae): functional significance of the apical dise and pyriform organ. Acta Zool. 69: 177-194.

Reed, C. G. 1991. Bryozoa. Pp. 85-245 in Reproduction of Marine Invertebrates, Vol. 6, Echinoderms and Lophophorates, A. C. Giese, J. S. Pearse, and V. B. Pearse, eds. The Boxwood Press, Pacific Grove, CA.

Reed, C. G., and R. M. Woollacott. 1982. Mechanisms of rapid morphogenetic movements in the metamorphosis of the bryozoan Bugula neritina (Cheilostomata, Cellularioidea). 1. Attachment to the substratum. J. Morphol. 172: 335-348.

Reed, C. G., J. M. Ninos, and R. M. Woollacott. 1988. Bryozoan larvae as mosaics of multifunctional ciliary fields: ultrastructure of the sensory organs of Bugula stolonifera (Cheilostomata, Cellularioidea). J. Morphol. 197: 127-145.

Ryland, J. S. 1960. The British species of Bugula (Polyzoa). Proc. Zool. Soc. Lond. 134: 65-105.

Ryland, J. S., and J. S. Porter. 2006. The identification, distribution, and biology of encrusting species of Alcyonidium (Bryozoa: Ctenostomatida) around the coasts of Ireland. Biol. Environ. 106: 19-33.

Santagata, S. 2002. Structure and metamorphic remodeling of the larval nervous system and musculature of Phoronis pallida (Phoronida). Evol. Dev. 4: $28-42$.

Santagata, S. 2004a. A waterborne behavioral cue for the actinotroch larva of Phoronis pallida (Phoronida) produced by Upogebia pugettensis (Decapoda: Thalassinidea). Biol. Bull. 207: 103-115.

Santagata, S. 2004b. Larval development of Phoronis pallida (Phoronida): implications for morphological convergence and divergence among larval body plans. J. Morphol. 259: 347-358.

Santagata, S. 2008. The morphology and evolutionary significance of the ciliary fields and musculature among marine bryozoan larvae. $J$. Morphol. 269: 349-364. [Published online October 25, 2007, DOI 10.1002/jmor. 10592.]

Santagata, S., and R. L. Zimmer. 2000. Comparing cell patterns of coronate bryozoan larvae with fluorescent probes. Pp. 365-375 in Proceedings of the 11th International Bryozoology Association Conference, A. Herrera-Cubilla and J. B. C. Jackson, eds. Smithsonian Tropical Research Institute, Republic of Panama.

Santagata, S., and R. L. Zimmer. 2002. Comparison of the neuromuscular systems among actinotroch larvae: systematic and evolutionary implications. Evol. Dev. 4: 43-54.

Shimizu, K., E. Hunter, and N. Fusetani. 2000. Localization of biogenic amines in larvae of Bugula neritina (Bryozoa: Cheilostomatida) and their effects on settlement. Mar. Biol. 136: 1-9.

Strathmann, R. R. 1993. Hypotheses on the origins of marine larvae. Annu. Rev. Ecol. Syst. 24: 89-117.

Stricker, S. A., C. G. Reed, and R. L. Zimmer. 1988a. The cyphonautes larva of the marine bryozoan Membranipora membranacea. I. General morphology, body wall, and gut. Can. J. Zool. 66: 368-383.

Stricker, S. A., C. G. Reed, and R. L. Zimmer. 1988b. The cyphonautes larva of the marine bryozoan Membranipora membranacea. II. Internal sac, musculature, and pyriform organ. Can. J. Zool. 66: 384398.

Taylor, P. D. 1990. Bioimmured ctenostomes from the Jurassic and the origin of the cheilostome Bryozoa. Palaeontology 33: 19-34.

Temkin, M. H., and R. L. Zimmer. 2002. Phylum Bryozoa. Pp. 411427 in Atlas of Marine Invertebrate Larvae, C. M. Young, M. A. Sewell, and M. E. Rice, eds. Academic Press, London.

Todd, J. A. 2000. The central role of ctenostomes in bryozoan phylogeny. Pp. 104-135 in Proceedings of the 1Ith International Bryozoology Association Conference, A. Herrera-Cubilla and J. B. C. Jackson, eds. Smithsonian Tropical Research Institute, Republic of Panama.

Valentine, J. W. 2004. On the Origin of Phyla. University of Chicago Press, Chicago.

Voronezhskaya, E. E., S. A. Tyurin, and L. P. Nezlin. 2002. Neuronal development in larval chiton Ischnochiton hakodadensis (Mollusca: Polyplacophora). J. Comp. Neurol. 444: 25-38.

Waeschenbach, A., M. J. Telford, J. S. Porter, and D. T. J. Littlewood. 2006. The complete mitochondrial genome of Flustrellidra hispida and the phylogenetic position of Bryozoa among the Metazoa. Mol. Phylogenet. Evol. 40: 195-207.

Wanninger, A., D. Koop, and B. M. Degnan. 2005a. Immunocytochemistry and metamorphic fate of the larval nervous system of Triphyllozoon mucronatum (Ectoprocta: Gymnolaemata: Cheilostomata). Zoomorphology 124: 161-170.

Wanninger, A., D. Koop, L. Bromham, E. Noonan, and B. M. Degnan. 2005b. Nervous and muscle system development in Phascolion strombus (Sipuncula). Dev. Genes Evol. 215: 509-518.

Wanninger, A., J. Fuchs, and G. Haszprunar. 2007. Anatomy of the serotonergic nervous system of an entoproct creeping-type larva and its phylogenetic implications. Invertebr. Biol. 126: 268-278.

Winston, J. E. 1982. Marine bryozoans (Ectoprocta) of the Indian River area, Florida. Bull. Am. Mus. Nat. Hist. 173: 99-176.

Winston, J. E. 2005. Re-description and Revision of Smitt's "Floridan Bryozoa" in the Collection of the Museum of Comparative Zoology, Harvard University. Virginia Museum of Natural History Memoir 7. $148 \mathrm{pp}$.

Woollacott, R. M. 1990. Structure and swimming behavior of the larva of Halichondria melanadocia (Porifera, Demospongiae). J. Morphol. 205: 135-145.

Woollacott, R. M., and R. L. Zimmer. 1972. Fine structure of a potential photoreceptor organ in the larva of Bugula neritina (Bryozoa). Z. Zellforsch. Mikrosk. Anat. 123: 458-469. 
Zimmer, R. L., and C. G. Reed. 1994. Morphology and ultrastructure of the larva of the bryozoan Tanganella muelleri (Ctenostomata: Victorellidae). Pp. 224-245 in Reproduction and Development of Marine Invertebrates, W. H. Wilson, S. A. Stricker, and G. L. Shinn, eds. The Johns Hopkins University Press, Baltimore.

Zimmer, R. L., and R. M. Woollacott. 1977a. Structure and classification of bryozoan larvae. Pp. 57-89 in The Biology of Bryozoans, R. M. Woollacott and R. L. Zimmer, eds. Academic Press, New York.

Zimmer, R. L., and R. M. Woollacott. 1977b. Metamorphosis, ancestrulae, and coloniality in bryozoan life cycles. Pp. $91-142$ in The
Biology of Bryozoans, R. M. Woollacott and R. L. Zimmer, eds. Academic Press, New York.

Zimmer, R. L., and R. M. Woollacott. 1989a. Larval morphology of the bryozoan Watersipora arcuata (Cheilostomata: Ascophora). J. Morphol. 199: 125-150.

Zimmer, R. L., and R. M. Woollacott. 1989b. Intercoronal cell complex of larvae of the bryozoan Watersipora arcuata (Cheilostomata: Ascophora). J. Morphol. 199: 151-164.

Zimmer, R. L., and R. M. Woollacott. 1993. Anatomy of the larva of Amathia vidovici (Bryozoa: Ctenostomata) and phylogenetic significance of the vesiculariform larva. J. Morphol. 215: 1-29. 


\section{Appendix}
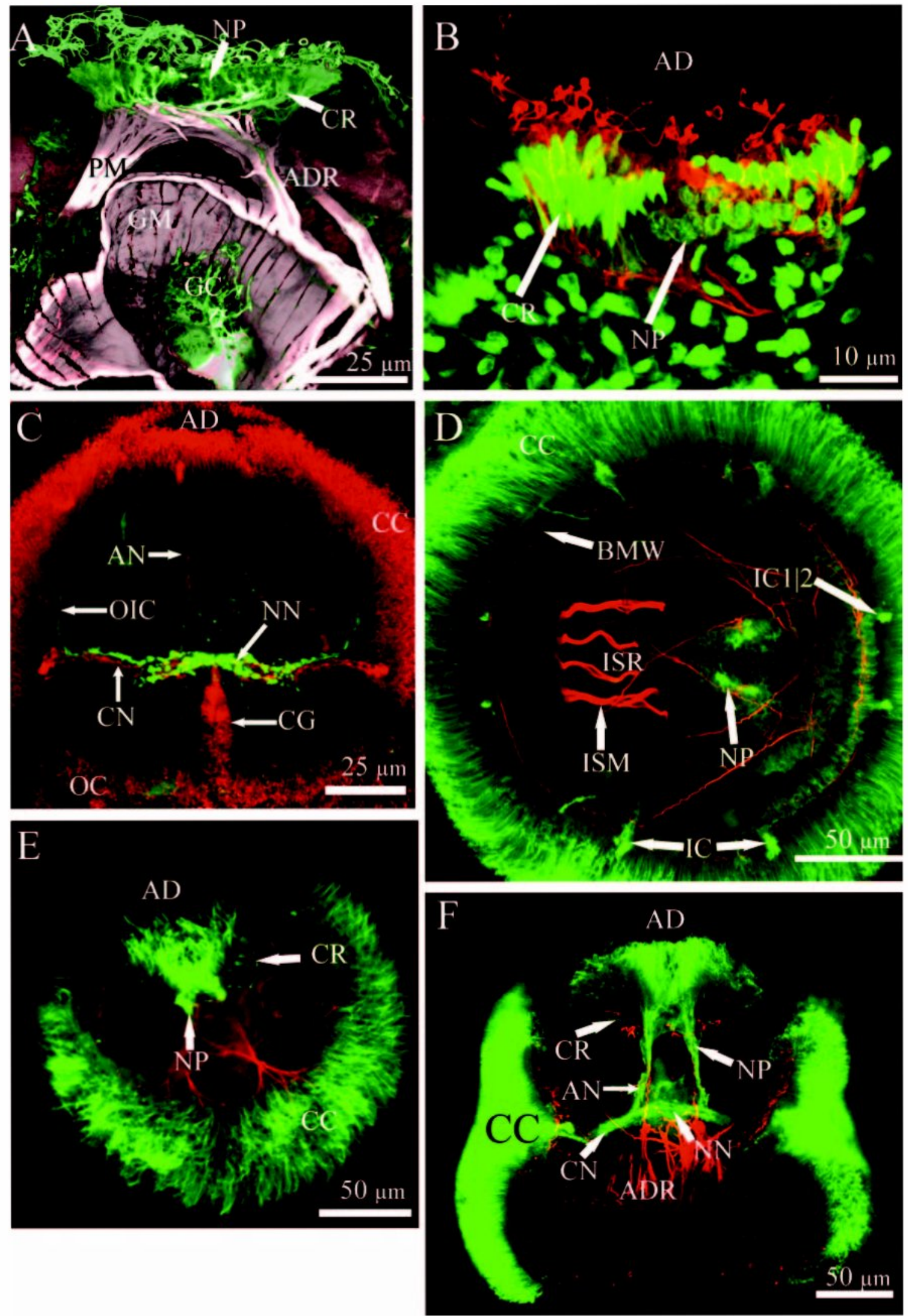


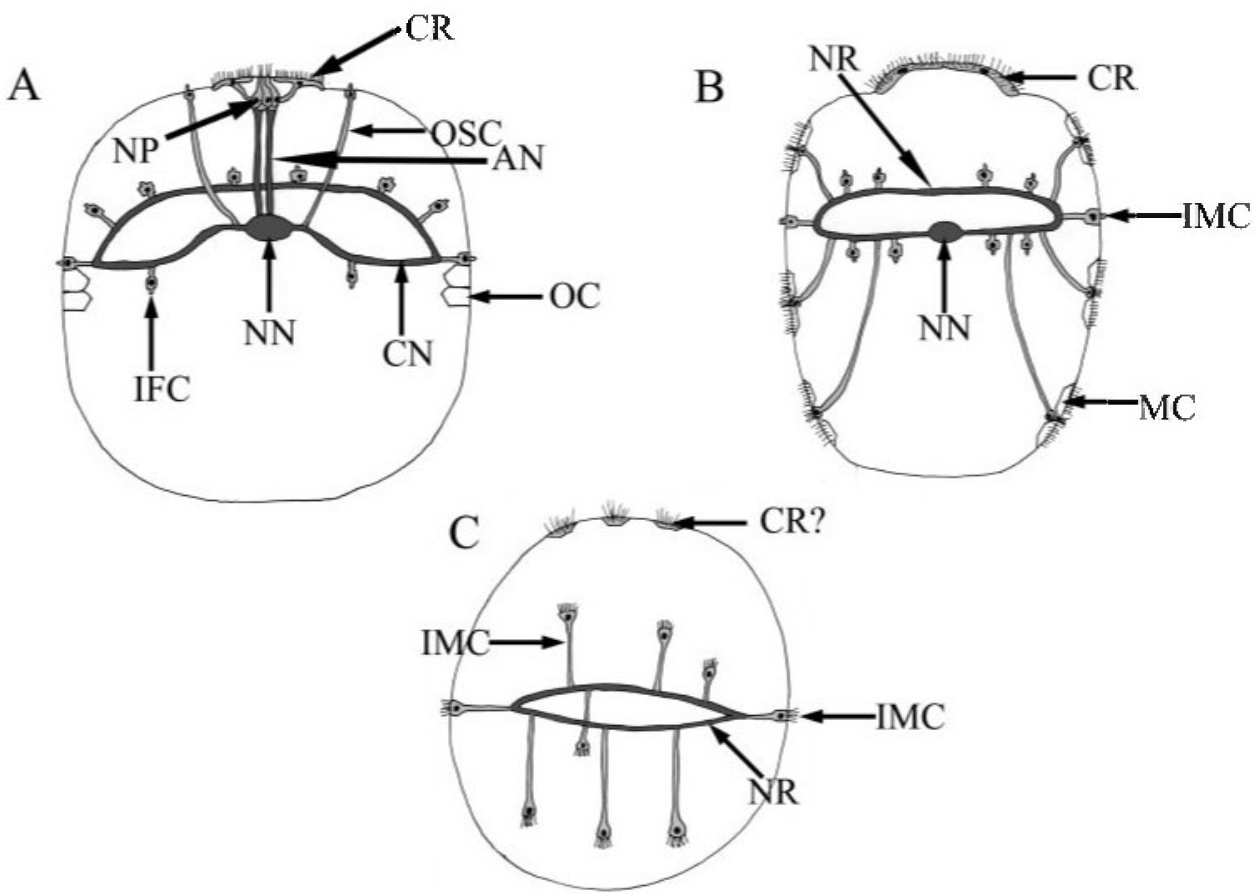

Appendix Figure 2. Representations of the larval nervous systems of select ctenostome and cyclostome bryozoan larval forms based on ultrastructural and immunohistochemical data (not drawn to scale). Abbreviations: AN, paraxial nerve cord; $\mathrm{CN}$, coronal nerve ring; CR, ciliated ray cells; IFC, infracoronal cell region; IMC, simple sensory neuron; MC, uniform multiciliated cell; NN, nerve nodule; NP, neural plate; NR, nerve ring; OC, oral ciliated cell; OSC, posterolateral ocelli. Nerves are colored dark gray and the neuronal fibers from single cells are colored light gray. (A) Oral view of a generalized larval nervous system of Aeverrillia setigera, ciliated sensory neurons on the larval surface are largely infracoronal (IFC) in this species, but supracoronal neurons (OSC) also occur. (B) Oral view of a generalized nervous system of Nolella stipata, depicting the absence of neural plate cells and paraxial nerve cords. Cell types similar to the ciliated ray cells (CR) are present in the apical disc, although it is not clear whether these cell types are integrated with the rest of the nervous system. It is possible these cells have fine neurites that make contact with the numerous ciliated tuft cells (IMC) that occur over the larval surface and make up most of the nervous system in this species. (C) Generalized depiction of the simple larva nervous system of Crisia elongata. Simple multiciliated neuronal cells (IMC) dispersed on the larval surface send fibers to an equatorial region in the larval body and make contact, forming a fiber-poor nerve ring (NR). A cell type with immotile cilia near the apical region of the larva may be similar to the ciliated ray cells (CR?) of other larval forms.

Appendix Figure 1. Neuromuscular diversity among cheilostome bryozoans. (A) Volume rendering of the apical region of the cyphonautes larva of Membranipora membranacea labeled for acetylated $\alpha$-tubulin (green) and the fibrous actin within muscle cells (pink). The gut musculature (GM), posterior medial muscle (PM), and the apical disc retractor muscles (ADR) are all striated. These latter muscles have numerous contact points with the ciliated ray cells (CR) and the neural plate cells (NP) in the apical disc. Ciliated cells are also present on the inner lining of the gut (GC). (B) Magnified sagittal projection of the neuronal cell types within the apical disc (AD) labeled for acetylated $\alpha$-tubulin (red) and nucleic acids (green). Note the differences in the nuclei of the ciliated ray cells (CR) versus those of the more centrally located neural plate cells (NP). (C) The coronate larva of Celleporaria sherryae dual-labeled for acetylated $\alpha$-tubulin (red) and serotonin (green). This projection is composed of cross sections through the apical dise and oral side of the larva. Serotonin is localized mainly in the nerve nodule (NN) and coronal nerve ring (CN). Serotonin is also found within the neuronal fibers from eyespots (OIC) and small fiber tracts along the ciliated groove. (D) The coronate larva of Schizoporella floridana dual-labeled for acetylated $\alpha$-tubulin (green) and fibrous actin (red). This projection shows internal neuromuscular features seen when looking down upon the apical disc. The large paired retractors that are associated with the apical disc and internal sac (ISM and ISR) are located directly posterior to the apical disc. Within the apical disc, the bilateral masses of neural plate cells (NP) are visible. At bilaterally symmetrical points on the larval surface, the small ciliated tufts of the intercoronal cells (IC and IC 112) are found beneath the cilia of the coronal cells (CC). Orthogonal meshwork of body wall musculature (BMW) is also visible. (E) The buguliform larva of Bugula stolonifera dual-labeled for acetylated $\alpha$-tubulin (green) and fibrous actin (red). Z-projection looking down on the apical disc (AD) within which the neuronal fibers of the ciliated ray cells (CR) make contact with adjacent neural plate cells (NP). Note that ciliated ray cells make only ipsilateral contact with neural plate cells. Coronal cells (CC) cover most of the larval surface in buguliform larvae. (F) The buguliform larva of Bugula neritina dual-labeled for acetylated $\alpha$-tubulin (green) and fibrous actin (red). Contacts between the ciliated ray cells and neural plate cells are the same as described for other species. The paraxial nerve cords (AN) merge into the nerve nodule where it joins the coronal nerve ring $(\mathrm{CN})$. Musculature in this species consists of a series of muscles that retract the apical dise (ADR). 